\title{
The Labor Market and Poverty in Sudan
}

May 2019

Poverty and Equity Global Practice, Africa 


\section{Standard Disclaimer:}

This volume is a product of the staff of the International Bank for Reconstruction and Development/The World Bank. The findings, interpretations, and conclusions expressed in this paper do not necessarily reflect the views of the Executive Directors of The World Bank or the governments they represent. The World Bank does not guarantee the accuracy of the data included in this work. The boundaries, colors, denominations, and other information shown on any map in this work do not imply any judgment on the part of The World Bank concerning the legal status of any territory or the endorsement or acceptance of such boundaries.

\section{Copyright Statement:}

The material in this publication is copyrighted. Copying and/or transmitting portions or all of this work without permission may be a violation of applicable law. The International Bank for Reconstruction and Development/ The World Bank encourages dissemination of its work and will normally grant permission to reproduce portions of the work promptly.

For permission to photocopy or reprint any part of this work, please send a request with complete information to the Copyright Clearance Center, Inc., 222 Rosewood Drive, Danvers, MA 01923, USA, telephone 978-750-8400, fax 978-750-4470, http://www.copyright.com/.

All other queries on rights and licenses, including subsidiary rights, should be addressed to the Office of the Publisher, The World Bank, 1818 H Street NW, Washington, DC 20433, USA, fax 202-522-2422, e-mail pubrights@worldbank.org. 
This paper was written by Alvin Etang Ndip (Senior Economist, GPV01) and Simon Lange (former JPO, GPV01), as part of the Sudan Programmatic Poverty Assessment (P164694). Overall guidance was provided by Pierella Paci (Practice Manager, GPV01). We would like to thank Korteh Akpey Kodjo (Consultant, GPV01) for research assistance. The authors would like to thank peer reviewers David Newhouse (Senior Economist, GPV07) and Supriyo De (Senior Economist, GPSJB) for providing valuable inputs.

\begin{tabular}{|ll|}
\hline Vice President & Hafez Ghanem \\
Country Director & Carolyn Turk \\
Senior Director & Carolina Sanchez-Paramo \\
Practice Manager & Pierella Paci \\
Task Team Leaders & Alvin Etang Ndip \\
\hline
\end{tabular}




\section{Summary}

Using the most recent household survey data, this paper examines the characteristics of Sudan's labor market as it relates to poverty outcomes. Several important aspects of the labor market are analyzed, including the relationship between labor market indicators and the demographic structure of the population, geographic location, education, and gender. It highlights the significant differences in labor market outcomes depending on the structure and distribution of the population and Sudan's labor market's many challenges across different dimensions, including demography, gender, and geography.

The four key messages can be summarized as follows: first, Sudan is at the verge of entering the earl-dividend stage of the demographic transition. Sudan's population, while still very young, is on track to enter into the early-dividend stage of the demographic transition within just a few years, raising the stakes for job creation and investment in human capita. Second, while we find evidence for an increase in employment and labor force participation at the national level, this increase seems to be driven by seasonal labor in agriculture and increasing economic hardship, respectively. In urban areas, however, unemployment increased sharply, especially among youth. And despite the overall increase in employment and labor force participation, Sudan's labor market still underperforms in comparison to its peers. Third, Sudan's labor market is characterized by large gender disparities, including in terms of employment opportunities and pay. Finally, we find no signs of the beginnings of a structural transformation over the time period we study; agriculture remains the mainstay of a large majority of employed Sudanese. Rather, labor productivity and real wages outside of agriculture declined markedly between 2009 and 2014, especially in sectors with links to the oil economy.

The paper offers policy insights to enhance the role of the labor market in reducing poverty and boosting shared prosperity in Sudan, key among which are 1) encouraging private sector growth, 2) overcoming gender discrimination in the labor market, 3) investing in agriculture and re-storing price incentives, and 4) further expanding access to quality education. 


\section{Introduction}

Sudan experienced a decade of high real economic growth during 1999-2011, driven by oil production and exportation. Following the discovery of oil in 1999, the size of Sudan's economy grew from US\$12 billion in 1999 to US\$65 billion in 2011-a 5.8 percent annual average growth. During this period, per capita income increased from US\$934 to US\$1,361 (constant 2010 US\$), raising Sudan to lower-middle-income status; government revenue increased from 10 percent of gross domestic product (GDP) to 18 percent of GDP.

Sudan missed an opportunity to transform and build the foundations of a more diversified economy. Over the years of the oil economy, service delivery remained weak and public investment was often inefficient (IMF, 2020). At the same time, the economy exhibited clear symptoms of Dutch Disease as growth in agricultural productivity, in particular, stalled.

With the secession of South Sudan in 2011, Sudan's oil economy came to an. A large fraction of Sudan's oil reserves were located in what is today South Sudan. A dispute over payments for the use of Sudan's infrastructure to transport oil to the Red Sea was settled only in late 2012 and the subsequent descent of South Sudan into civil war at the end of 2013 has meant that Sudan experienced an adverse natural resource shock. Real GP growth dropped form 5.8\% between 1999 and 2011 to only $4.1 \%$ between 2012 and 2017

Well-paying, productive jobs are crucial to sustainable economic growth with poverty reduction. Sustainable economic growth with poverty reduction has typically been accompanied by structural transformation in which the share of employment of sectors with high value addedparticularly labor-intensive manufacturing — increases at the expense of agriculture (Rodrik 2013). As agriculture is typically associated with low levels of labor productivity and limited potential for productivity growth, structural change toward manufacturing in particular is commonly associated with both static and dynamic gains in labor productivity. However, in 2011, when the last Labor Force Survey (LFS) was conducted, agriculture still accounted for the vast majority of employment in Sudan, followed by services. Manufacturing accounted for only a small fraction.

Providing quality employment opportunities remains key for development in Sudan. Among Sudan's strategy for long-term economic growth and sustainable development is the goal to achieve and sustain peace and political and economic stability, enhance economic diversification and regionally balanced growth, build human resources and institutions, and achieve self-reliance based on domestic capital and labor. Job creation and reduction in unemployment is a crucial component of this strategy and for achieving equity and pro-poor growth (as reflected in Sudan's 2012 Interim Poverty Reduction Strategy Paper [IPRSP]). As Sudan suffers from political instability and conflict and continues to face large regional disparities due to unbalanced development, achieving these objectives requires a good understanding of the structure and dynamics of the labor market.

Little is known about either recent levels and trends in labor force participation and employment opportunities or the link between labor market outcomes and poverty in Sudan. The 2009 National Household Baseline Survey (NHBS) indicated that unemployment was a major cause of poverty in Sudan and addressing it was at the core of the 2012 IPRSP. However, a knowledge gap exists with regard to current levels and trends in labor market outcomes and their 
relationship to levels and changes in poverty and inequality. The need for this analysis is stronger now at a time when Sudan is going through a socioeconomic and political transformation. The availability of the 2014/15 National Household Budget and Poverty Survey (NHBPS) provides and opportunity to narrow this knowledge gap. It remains the most up-to-date source of microdata on the Sudanese labor market.

This paper provides and analysis of levels and trends in Sudan's labor market as well as their links to poverty. The primary data sources used for the analyses are the labor market modules of the 2009 and 2014/15 household surveys. The latest survey data (2014/15) provide a better and more recent understanding of the structure of Sudan's labor market. An analysis of structural transformations between the early days of the post-oil economy and the most recent data points available will shed light on the extent and potential for structural transformation. Several important aspects of the labor market are analyzed, including the relationship between labor market indicators and the socio-demographic characteristics of the population. It highlights the significant differences in labor market outcomes across different sections of the population. The paper documents that the labor market in Sudan faces many challenges across different dimensions, including demography, gender, and geography. This is primarily an analysis of labor demand (we look at household data, not firm-level data) and that the household data do not allow us to distinguish formal from informal and public- from private-sector employment.

The paper will inform the country policy dialogue and the World Bank's program in Sudan. This work was undertaken as part of the Sudan Programmatic Poverty Assessment, whose development objective is to contribute to a better understanding of the current nature of poverty and inequality in Sudan as well as drivers of poverty, inequality, and shared prosperity. It aims to inform the dialogue on policies to achieve inclusive growth and reductions in poverty in the future.

\section{The paper's main findings can be summarized as follows:}

1. Imminent early-dividend: Sudan's population, while still very young, is on track to enter into the early-dividend stage of the demographic transition within just a few years. Fertility rates have been falling for four decades and there are signs that the age pyramid's base may be narrowing, raising the stakes for job creation and investment in human capital.

2. Rising unemployment in urban areas and among youth. We find evidence for an increase in employment and labor force participation at the national level that seems to be driven by an increase in the demand for seasonal labor in agriculture and increasing economic hardship, respectively. In urban areas, however, unemployment increased sharply, especially among youth. And despite the overall increase in employment and labor force participation, Sudan's labor market still underperforms in comparison to its peers.

3. Large gender disparities. There are large disparities between women and men in terms of the quantity and quality of labor market activities they engage in. Only 33 percent of all working-age women participate in the labor force compared to about 75 percent of working-age men. Yet despite lower labor force participation, women are more likely to be unemployed. A vast majority of those in unpaid work are women. Average wages of women are only $60 \%$ of those of men. 
4. No structural transformation. Agriculture remains the mainstay of a large majority of employed Sudanese - there is no evidence of structural transformation over the time period we study here. In fact, labor productivity and real wages outside of agriculture declined markedly between 2009 and 2014, especially in sectors with links to the oil economy.

The paper is organized as follows. Section 2 provides information about the demographic situation of Sudan as well as its links to the labor market. This includes the population distribution by gender, age, and location; age dependency ratios; and education levels. Section 3 describes key labor market trends between 2009 and 2014. ${ }^{1}$ The labor market outcomes analyzed include unemployment rate, employment to working-age population, and labor force participation. Sudan is compared with peer countries to put the results in perspective. This section also explores drivers of labor force participation and non-participation. Section 4 documents the characteristics of the employed, including by economic sector, gender and educational attainment. Section 5 looks at levels and trends in labor productivity and wages. Section 6 examines the link between employment and poverty. Section 7 highlights some policy implications of the findings.

\section{Demographic trends}

\section{Population growth and the demographic transition}

Understanding the age and gender composition of the population is key for the analysis of labor markets and their link to poverty. The size, growth, distribution, and structure of the population have a direct effect on labor supply. Current trends can be used to gauge future changes in labor supply.

Sudan's labor force is growing rapidly - more quickly than the overall population. Sudan's population was estimated at 41.5 million in 2018 (World Development Indicators [WDI]). Figure 1 shows the population pyramid of Sudan in 2014, based on data from the 2014/15 NHBPS. It remains broad-based, indicating a young population. In fact, more than two in five (42.5 percent) Sudanese are below the age of 15 and only 4.2 percent are older than 64 . About 60 percent of the population is below the age of 25 . Every second Sudanese is under 20 -about 49 percent of the urban population and over 55 percent of the rural population is under the age of 20 .

However, the demographic composition of Sudan's population is about to shift. The population grew at an estimated rate of 2.4 percent in 2019, slightly lower than the 2.7 percent estimated for the Sub-Saharan Africa region and much lower than the 3.8 percent growth Sudan was experiencing in the mid-1990s. Fertility has been falling for decades, from around 6.9 births per woman in the early 1980s to only 4.4 births in 2018 (Figure 1b).

\footnotetext{
${ }^{1}$ The labor module of the 2014/15 survey was conducted in November 2014. We will thus refer to 2014 throughout the paper.
} 
Figure 1: Key population trends in Sudan

(a) Population pyramid in 2014

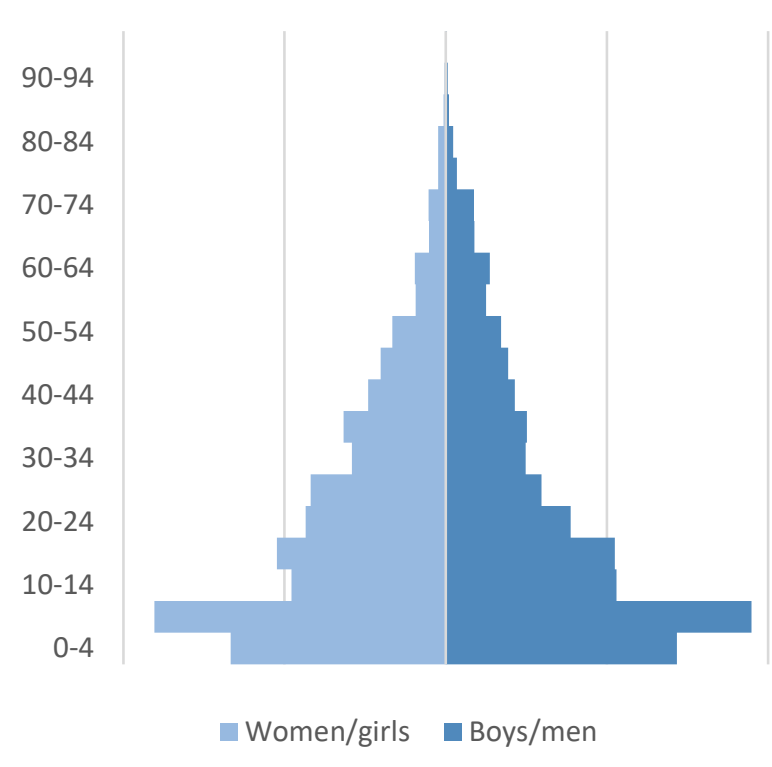

(b) Total fertility rate and dependency ratio

in Sudan and Sub-Saharan Africa, 1980-

2016, and projection for Sudan

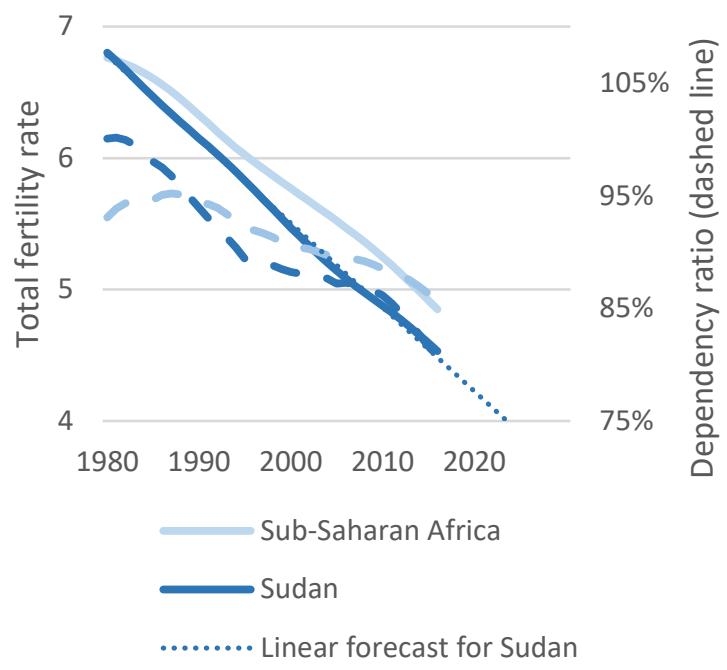

Source: Authors' calculations based on 2014/15 NHBPS (left panel) and WDI data (right panel).

Sudan may be close to entering the early-dividend stage of the demographic transition. Four children per woman, a rate Sudan would hit by about 2023 on current trends, is often seen as a critical threshold at which countries enter the 'early-dividend' stage of the demographic transition, when a decrease in child mortality followed by a decrease in fertility produces a 'bulge' generation and a period when a country has a large number of working-age people and a smaller number of dependents.

The early-dividend stage constitutes both major challenges and significant opportunities. A higher ratio of working-age adults to dependents can give a boost to the economy provided there are labor opportunities for these workers. Smaller family sizes also imply that both families and governments have more resources to invest in health and education per child and that women are in a better position to enter the labor force. On the other hand, a failure to productively employ large cohorts of youth can be socially disruptive (Urdal 2006).

Age-dependency ratios vary significantly across states. Northern and central states have higher shares of working-age adults while the Kordofans, Darfur, and Blue Nile states have particularly young populations. Dependency ratios capture variations in the proportions of children, elderly people, and working-age people in the population that imply the dependency burden that the working-age population bears in relation to children and the elderly. ${ }^{2}$ The overall survey estimate of the age-dependency ratio (dependents young and old as a share of working-age people) is 0.88 percent (Error! Reference source not found.), only slightly higher than the projection reported

\footnotetext{
${ }^{2}$ Dependency ratios capture only the age composition of a population, not economic dependency. Some children and elderly people are part of the labor force and many working-age people are not. The standard definition of the workingage population is people of ages between 15 and 64 .
} 
in the WDI for 2014 (Figure 1b). ${ }^{3}$ Age dependency ratios vary from about 65-70 percent (two dependents out of five) in Northern state, Khartoum, Al-Gezira, and Red Sea states to more than 100 percent (one in two) in Kordofan, Darfur, and Blue Nile states (Error! Reference source not found.).

Figure 2: Age dependency ratios, 2014

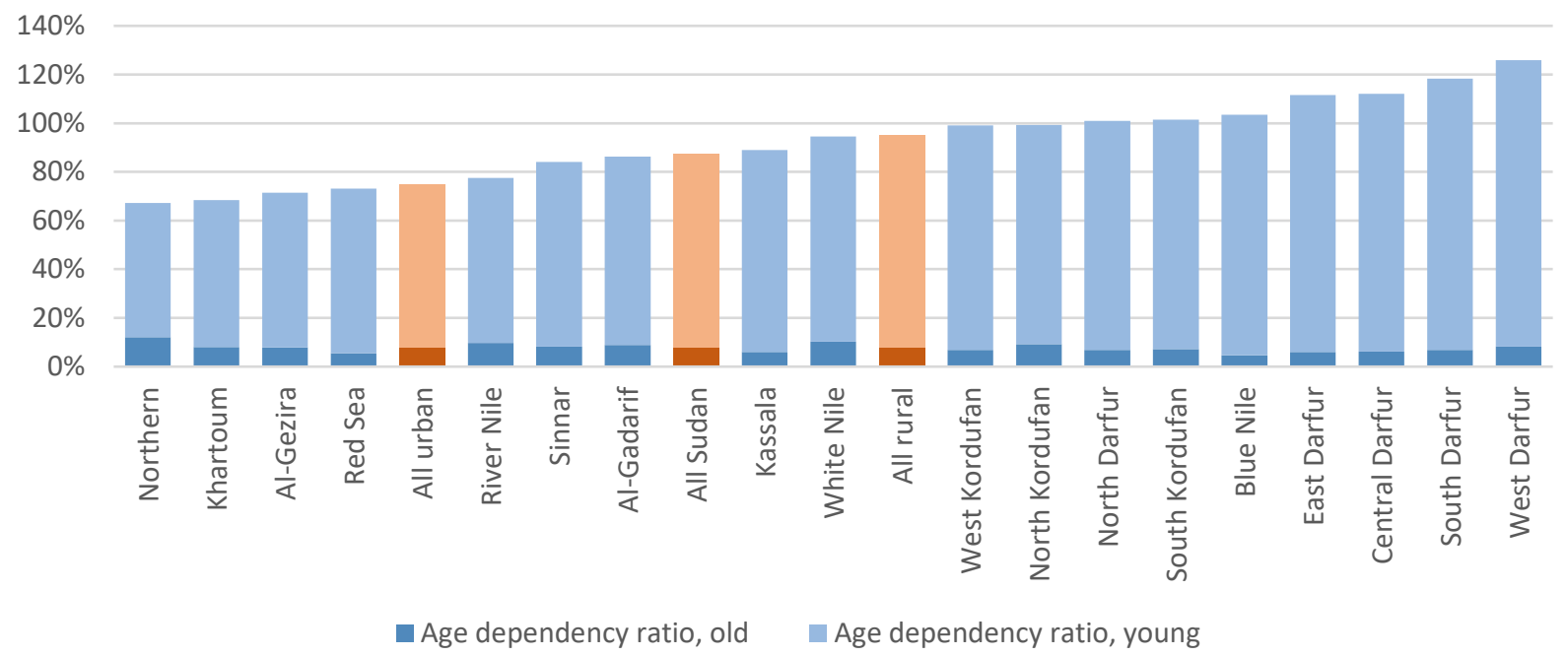

Source: Authors' calculations based on NHBPS 2014/15.

Reaping the demographic dividend will be crucial for Sudan's future prospects. At current rates, Sudan's economy will have to create roughly 500,000 new jobs each year for the foreseeable future just to keep unemployment and non-participation from rising. This raises the stakes both for investment in human capital as well as supply-side policies that accelerate job creation. The imminent demographic dividend provides Sudan with an opportunity to boost growth and reduce poverty - but this hinges on its economy being capable of generating adequate employment opportunities to absorb existing and new labor market entrants.

\section{Educational attainment}

Education levels are substantially lower in rural areas than in urban areas and lower for women than for men. Estimates from the 2014 survey suggest that over one-third (37 percent) of Sudan's adult population has never attended a formal school, 41 percent have at most primary school education, 15 percent have at most secondary school education, and only seven percent have some post-secondary education. Figure 4 disaggregates the education level by gender and location, showing heterogeneity across gender and location. Two key messages emerge from Figure 4: people living in rural areas are less educated than the urban population and education levels are lower for women than men.

\footnotetext{
${ }^{3}$ Age structure in the World Bank's population estimates, which are made available through the WDI, is based on the age structure in United Nations Population Division's World Population Prospects.
} 
Figure 3: Education level by gender and location

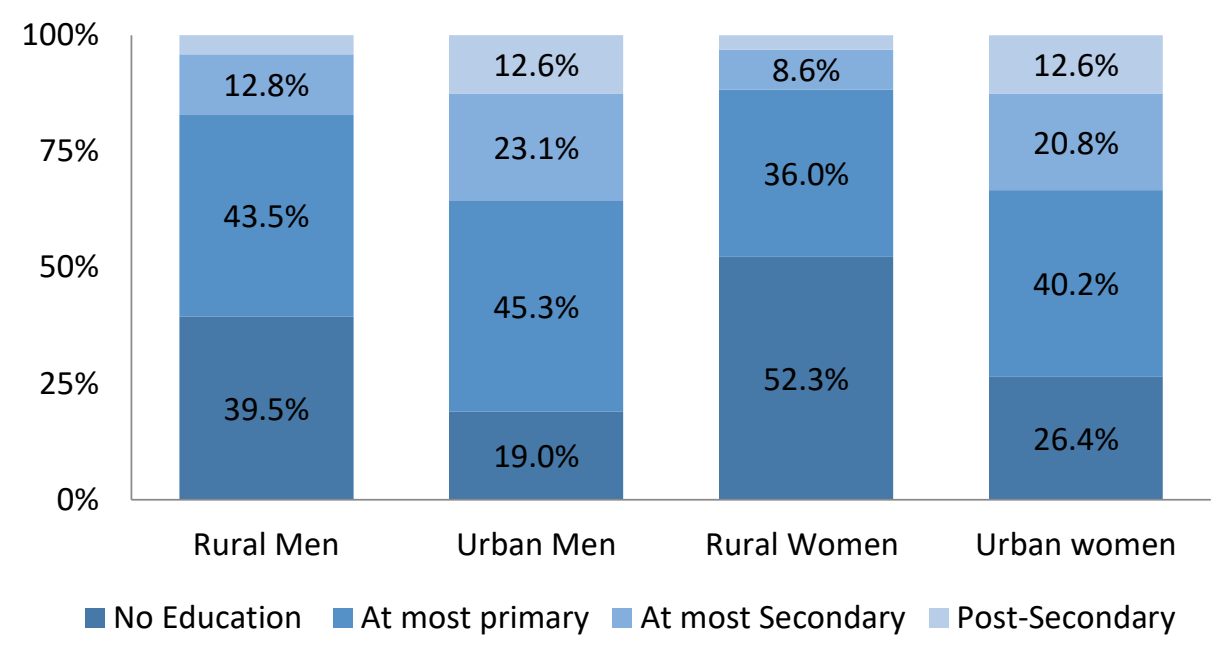

Source: Authors' calculations based on NHBPS 2014/15.

Younger cohorts are better educated. Figure 5 shows the percentage of the population with each level of education attainment for five-year age brackets. On average, younger cohorts are substantially more educated than older cohorts. About 80 percent of people ages 65 or older have never attended any formal school while the corresponding number is only 32 percent for people between 20 and 24 years. Furthermore, almost 15 percent of people between 20 and 24 years have a post-secondary level of education compared to only 2 percent for people ages 65 and older. ${ }^{4}$

Figure 4. Education level by cohort

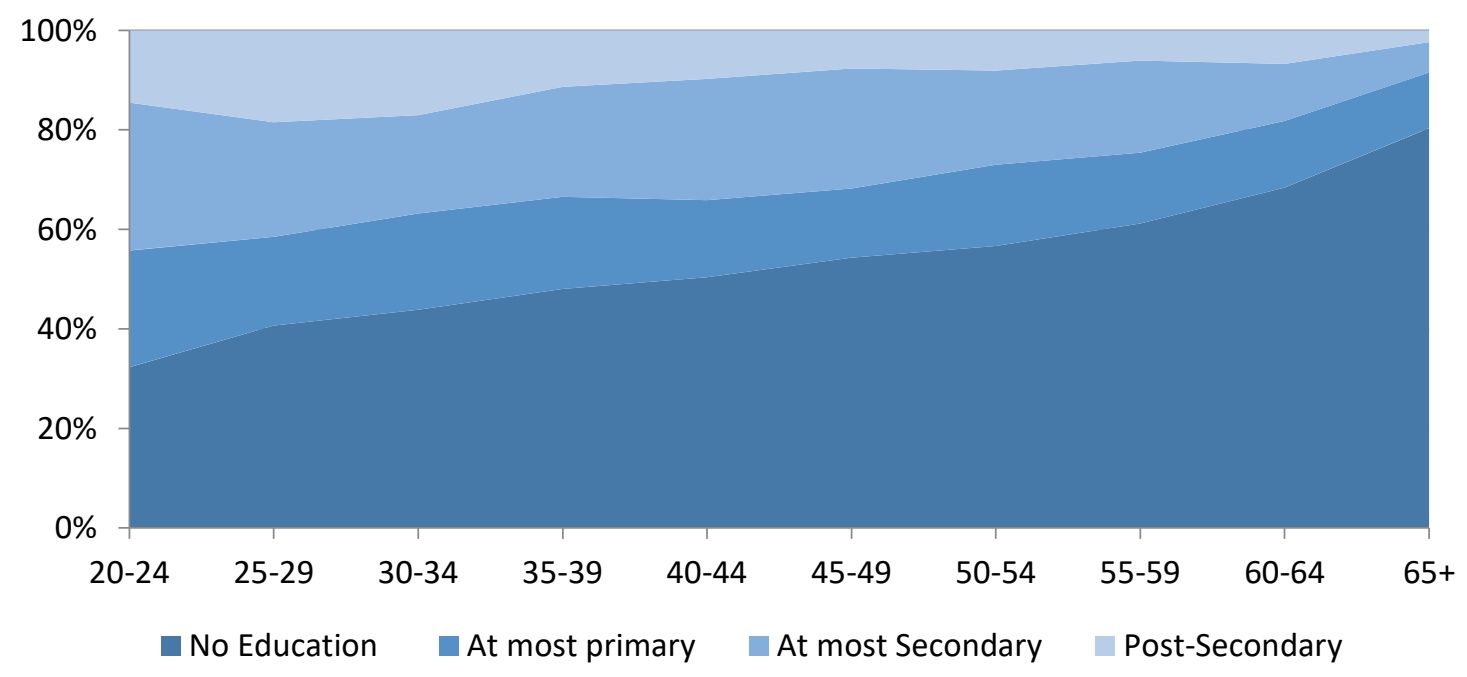

Source: Authors' calculations based on NHBPS 2014/15.

\footnotetext{
${ }^{4}$ This cohort difference in years of completed education reflects rising education enrollment and spending through time, documented in World Bank (2014).
} 


\section{Key labor market trends, 2009-2014}

Labor force participation and employment rates increased significantly while the unemployment rate declined modestly between 2009 and 2014. Table 1 presents basic labor market indicators ${ }^{5}$ for 2009 and 2014 as well as the differences between the two years. The survey results show that labor force participation and employment as a share of the working-age population (15-64 years) increased by more than five percentage points from 48.3 percent in 2009 to about 53.5 percent in 2014. The unemployment rate decreased slightly to 11.3 percent in 2014 from 12.5 percent in 2009. ${ }^{6}$ The broad unemployment rate, which includes working-age individuals who are not actively seeking work because they are discouraged in addition to those unemployed, fell by 2.4 percentage points. The share of working-age individuals that have given up actively looking for employment has remained nearly unchanged at 5.6 percent.

Table 1: Basic labor market indicators, 2009 and 2014

\begin{tabular}{|c|c|c|c|c|}
\hline & $2009(\%)$ & $2014(\%)$ & Difference (\%) & $p$-value \\
\hline Unemployment rate & 12.5 & 11.3 & -1.2 & 0.141 \\
\hline Broad unemployment rate & 19.3 & 16.9 & -2.4 & 0.008 \\
\hline Employment to working-age population & 42.2 & 47.4 & 5.2 & 0.000 \\
\hline Labor force participation & 48.3 & 53.5 & 5.2 & 0.000 \\
\hline Working-age population to total population & 53.5 & 53.3 & -0.2 & 0.656 \\
\hline
\end{tabular}

Source: Authors' calculations based on NBHS 2009 and NHBPS 2014.

Sudan underperforms on labor market indicators compared to its income and regional peers. To put the results into perspective, we benchmark Sudan to other lower middle-income countries ${ }^{7}$ (LMICs) and averages for Sub-Saharan Africa (SSA) and the Middle East and North Africa (MENA). Table 2 shows these comparisons. The overall employment rate in Sudan is one of the lowest in the SSA region, and lower than the average for LMICs. Similarly, the unemployment rate and non-participation in the labor force are much higher in Sudan compared to averages for LMICs, SSA, and the neighboring MENA region.

\footnotetext{
5 The analysis in this paper does not strictly follow the terminology and definitions of the International Labour Organization (ILO). It is important to underscore that the conventional measures of labor market based on the ILO definition need to be interpreted with caution in the context of Sudan where the bulk of labor market activities is nonwage and much of the work takes place outside the labor market as typically understood in more developed economies. The ILO defines employed as a person having worked during the reference week for at least one hour for pay (or without pay) for profit, in-kind, or family business: those who were reported as house-workers, students, income recipients, old agers, persons with no hope of finding a job, or disabled persons were categorized as outside of the labor force. The unemployed are those who were seeking work or were available for work during the reference week but did not work during the reference week. This included those who had worked before but were unemployed during this reference week. Also included in this category were those who considered themselves unemployed but had never worked before (that is, were actively looking for work for the first time or would have worked if they found a job). The analysis of employment includes both wage and non-wage employment.

${ }^{6}$ There are differences in the design of the labor modules between the two surveys: first, the recall period changed from 7 days in 2009 to 10 days in 2014. Second, the order in which questions were asked changed, with implications for skipping patterns.

${ }^{7}$ Sudan was classified as a lower middle-income country (LMIC) at the time the data were collected. It has since been re-classified as a low-income as a result of a revision of the GNI series for 2009-2018.
} 
Table 2: Benchmarking Sudan's labor market indicators by income group and region

\begin{tabular}{|l|c|c|c|c|}
\hline & $\begin{array}{c}\text { Sudan } \\
(\boldsymbol{\%})\end{array}$ & LMICs (\%) & $\begin{array}{c}\text { Sub-Saharan } \\
\text { Africa (\%) }\end{array}$ & $\begin{array}{c}\text { Middle East and } \\
\text { North Africa (\%) }\end{array}$ \\
\hline Unemployment rate & 11.3 & 2.5 & 5.0 & 7.5 \\
\hline Employment rate & 47.4 & 56.8 & 63.8 & 50.9 \\
\hline Inactive/Not in the labor force & 46.5 & 40.7 & 31.2 & 41.5 \\
\hline Working-age population & 53.3 & 62.7 & 53.3 & 60.8 \\
\hline
\end{tabular}

Source: Peer calculations by Dino Merotto (2019).

The increase in labor force participation resulted mainly from more women entering the labor force; however, the share of women participating in the labor force remains low compared to men. Over half of the jobs added between 2009 and 2014 were filled by women. Labor force participation among women increased by nearly 10 percentage points compared to about two percentage points among men (Figure 6a). For women, unemployment and broad unemployment decreased by four and seven percentage points, respectively. For men, the corresponding numbers are one and two percentage points.

Unemployment increased in urban areas and among the richest 20 percent while it decreased in rural areas and among the bottom 40 percent. The overall decrease in unemployment masks large shifts across location and quintiles of the expenditure distribution and across localities (Figure 6b). The unemployment rate fell among the poorest 20 percent of the population from about 18 percent in 2009 to 10 percent in 2014, reflecting a 45 percent decrease. For the top 20 percent, unemployment increased by about 30 percent from nine percent to nearly 12 percent during the same period. That the unemployment rate is higher in urban areas than in rural areas constitutes a reversal of the pattern observed in 2009. 
Figure 5: Labor force participation rates and unemployment rate by gender, quintile, locality, and year

(a) Labor force participation rate

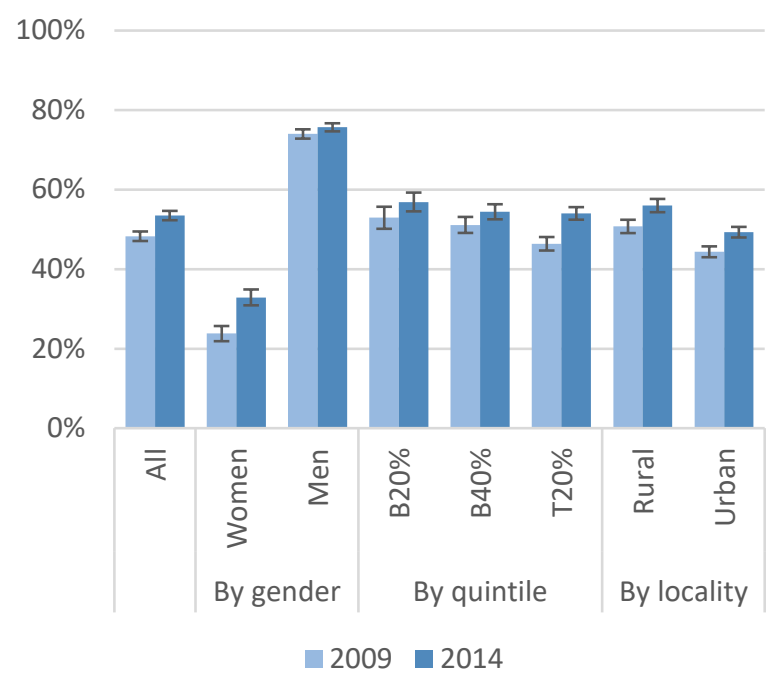

(b) Unemployment rate

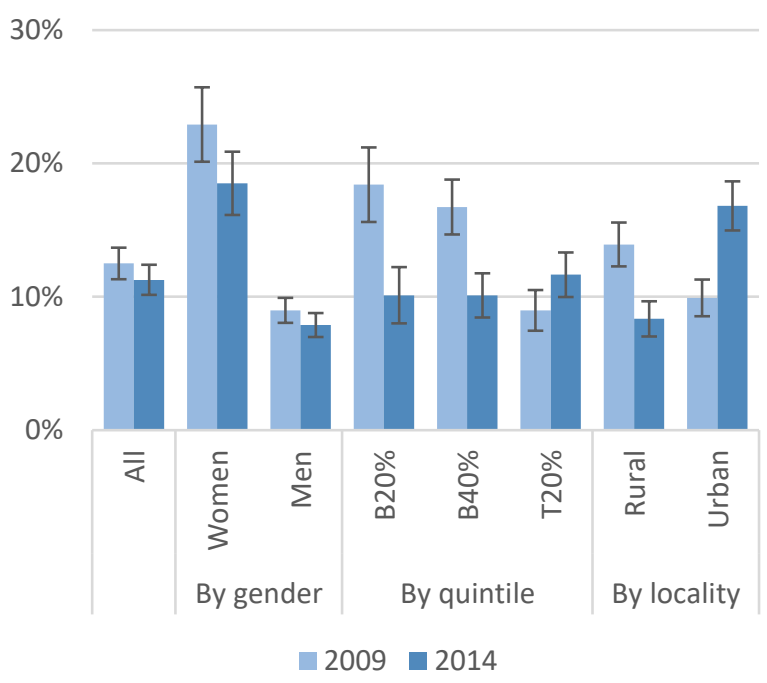

Source: Authors' calculations based on NHBS 2009 and NHBPS 2014/15.

Note: 95 percent confidence intervals indicated.

However, stark gender differences remain in unemployment and labor force participation. Only one in every three working-age women are either employed or actively seeking employment, compared to three in four men. Rural areas seem to have higher rates of female labor force participation. Low female labor force participation is particularly pronounced in the Eastern, Northern, Central, and Khartoum regions, all of which had female labor force participation rates of 25 percent or less in 2014 (Table 3). On the contrary, over half of all working-age women in Darfur and Kordufan regions were economically active in 2014.

The low rate of female participation in the labor force is explained in part by legal obstacles to women's economic activities in Sudan. There are significant legal obstacles to women's labor market opportunities in Sudan. Sudanese women often cannot in the same way as men work the same night hours, perform jobs deemed hazardous, arduous, or morally inappropriate, perform the same tasks, or work in the same industries (World Bank, 2020). 
Table 3: Labor market indicators by rural/urban and region, 2009 and 2014

\begin{tabular}{|l|c|c|c|c|c|c|c|c|}
\hline & \multicolumn{3}{|c|}{$\begin{array}{c}\text { Unemployment rate } \\
(\%)\end{array}$} & $\begin{array}{c}\text { Youth unemployment } \\
\text { rate (\%) }\end{array}$ & \multicolumn{2}{c|}{$\begin{array}{c}\text { Labor force } \\
\text { participation (\%) }\end{array}$} & \multicolumn{2}{c|}{$\begin{array}{c}\text { Female labor force } \\
\text { participation (\%) }\end{array}$} \\
\hline & $\mathbf{2 0 0 9}$ & $\mathbf{2 0 1 4}$ & $\mathbf{2 0 0 9}$ & $\mathbf{2 0 1 4}$ & $\mathbf{2 0 0 9}$ & $\mathbf{2 0 1 4}$ & $\mathbf{2 0 0 9}$ & $\mathbf{2 0 1 4}$ \\
\hline Sudan & 12.5 & 11.3 & 20.2 & 22.3 & 48.3 & 53.5 & 23.8 & 32.9 \\
\hline Rural & 13.9 & 8.3 & 20.4 & 15.6 & 50.7 & 56.0 & 26.8 & 35.4 \\
\hline Urban & 9.9 & 16.8 & 19.7 & 39.3 & 44.4 & 49.3 & 18.9 & 28.8 \\
\hline By region \\
\hline Northern & 10.1 & 16.6 & 22.4 & 38.5 & 41.3 & 46.7 & 9.7 & 16.7 \\
\hline Eastern & 9.0 & 7.1 & 17.5 & 14.8 & 43.2 & 47.0 & 8.3 & 16.3 \\
\hline Khartoum & 8.8 & 16.6 & 18.0 & 41.7 & 41.8 & 46.2 & 15.4 & 25.1 \\
\hline Central & 7.8 & 15.1 & 14.3 & 30.6 & 45.1 & 47.5 & 16.6 & 18.8 \\
\hline Kordufan & 21.1 & 7.2 & 26.4 & 14.0 & 62.7 & 64.3 & 47.1 & 51.0 \\
\hline Darfur & 16.9 & 7.8 & 22.9 & 13.0 & 56.4 & 67.9 & 42.2 & 61.9 \\
\hline
\end{tabular}

Source: Authors' calculations based on NBHS 2009 and NHBPS 2014/15.

There exists substantial regional variation in the levels and trends of labor market indicators. Between 2009 and 2014, unemployment rates increased in the Northern, Central, and Khartoum regions, while it decreased substantially in the Kordufan and Darfur regions, with the Eastern region experiencing a slight decrease. Similar regional trends are observed for youth unemployment. While labor force participation rates increased in all regions, but the increase is more pronounced in some regions than others (11.5 percentage points in Darfur compared to 1.6 percentage points in Kordufan). The significant drop in unemployment and considerable rise in labor force participation in Kordufan and Darfur is consistent with increasing labor supply being met by increasing labor demand.

Youth unemployment increased in Sudan, driven entirely by youth unemployment in urban areas. Between 2009 and 2014 youth unemployment increased from 20 percent to 22 percent (Figure 7a). Male youth experienced an increase in unemployment. Youth in the richest 20 percent of the consumption distribution also experienced a rise in unemployment. But the increase among urban youth is more pronounced than among urban Sudanese in general. Urban youth unemployment doubled from about 20 percent in 2009 to about 40 percent in 2014. For urban workers, unemployment rates increased considerably for nearly everyone below 50 years, particularly for those below 25 years, the youth (Women fail to transition into employment after education. Figure 8 presents a breakdown of employment and labor force participation by age and gender in rural and urban areas. While women, especially in urban areas, initially have a similar likelihood as men to be in education, they are less likely to transition into employment. Compared to men, urban women between the ages of 20 and 39 are particularly likely to be unemployed. While around four in five men are in employment by the time they are 30, the share of women in employment peaks at around 40 percent both for rural and urban women for women - and in only does so when they are in their 40s.

The rising trend of urban youth unemployment and low levels of female participation in the labor force is a concern both for economic and political reasons. The access for women and youth to economic opportunities such as employment contributes to inclusive growth and is crucial for development. It has been argued that increasing female labor force participation to the levels of men could boost annual global GDP by 26 percent in 2025 compared with a business-as-usual scenario, and that in Sub-Saharan Africa, 40-45 percent of the potential increase in output could come from shifting women into high-productivity sectors (McKinsey Global Institute, 2015). Sudan's 
youth are instrumental for achieving the country's development and poverty reduction goals, particularly given that about 60 percent of its population is below the age of 25 . However, youth need to be equipped with the skills and opportunities required to reach their potential, support development, and contribute to peace and security

Unemployment is a major cause of poverty in Sudan and addressing it should be at the core of the impending Poverty Reduction Strategy Paper (PRSP) or development strategy. As shown further in section 6, unemployment is a major determinant of poverty in Sudan, especially in urban areas. It would be useful to have a better understanding of the constraints faced by youth and women in accessing employment opportunities. Building on this work, additional research is being undertaken in this regard.

b).

Figure 6: Youth unemployment rate by gender, quintile, locality, and year, and unemployment rate by age in urban areas

(a) Youth unemployment

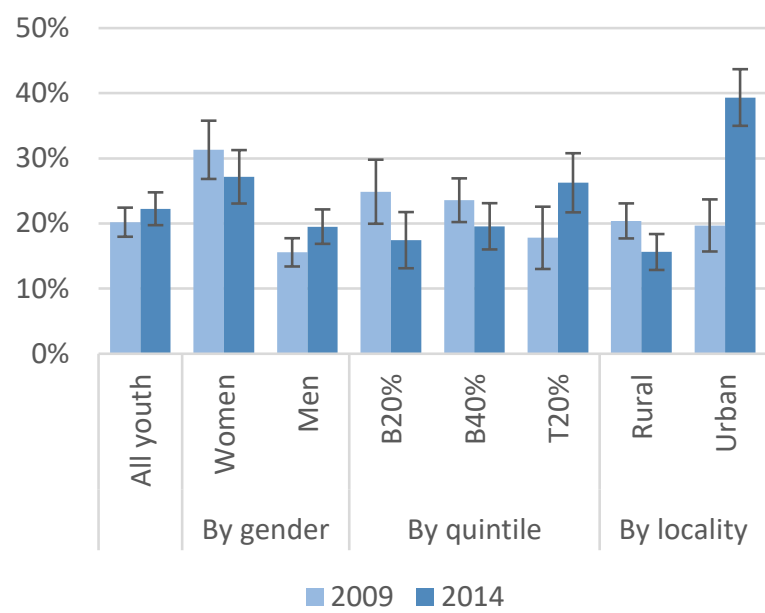

(b) Urban unemployment by age

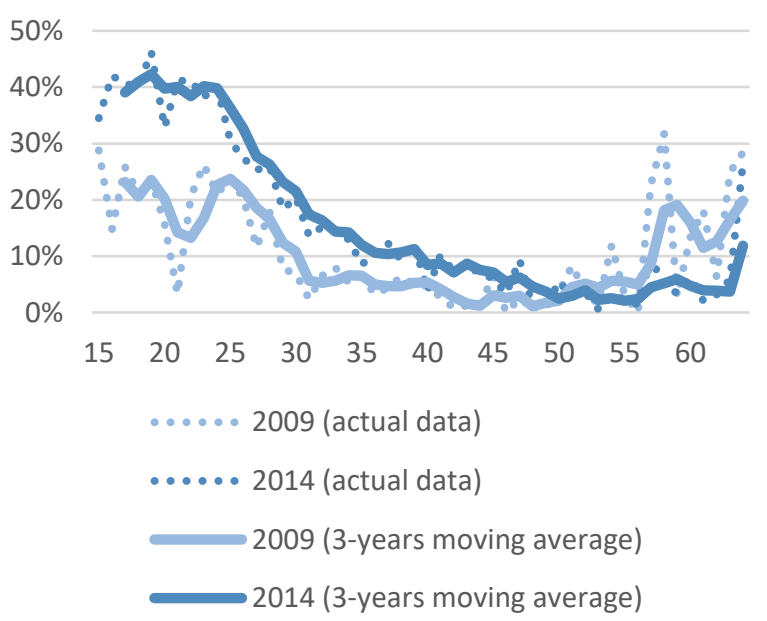

Source: Authors' calculations based on NHBS 2009 and NHBPS 2014/15.

Note: 95 percent confidence intervals indicated in panel (a).

Women fail to transition into employment after education. Figure 8 presents a breakdown of employment and labor force participation by age and gender in rural and urban areas. While women, especially in urban areas, initially have a similar likelihood as men to be in education, they are less likely to transition into employment. Compared to men, urban women between the ages of 20 and 39 are particularly likely to be unemployed. While around four in five men are in employment by the time they are 30, the share of women in employment peaks at around 40 percent both for rural and urban women for women - and in only does so when they are in their 40s.

The rising trend of urban youth unemployment and low levels of female participation in the labor force is a concern both for economic and political reasons. The access for women and youth to economic opportunities such as employment contributes to inclusive growth and is crucial for development. It has been argued that increasing female labor force participation to the levels 
of men could boost annual global GDP by 26 percent in 2025 compared with a business-as-usual scenario, and that in Sub-Saharan Africa, 40-45 percent of the potential increase in output could come from shifting women into high-productivity sectors (McKinsey Global Institute, 2015). Sudan's youth are instrumental for achieving the country's development and poverty reduction goals, particularly given that about 60 percent of its population is below the age of 25 . However, youth need to be equipped with the skills and opportunities required to reach their potential, support development, and contribute to peace and security

Unemployment is a major cause of poverty in Sudan and addressing it should be at the core of the impending Poverty Reduction Strategy Paper (PRSP) or development strategy. As shown further in section 6, unemployment is a major determinant of poverty in Sudan, especially in urban areas. It would be useful to have a better understanding of the constraints faced by youth and women in accessing employment opportunities. Building on this work, additional research is being undertaken in this regard.

Figure 7: Employment and labor force participation by cohort

\section{Panel A: Rural Men}

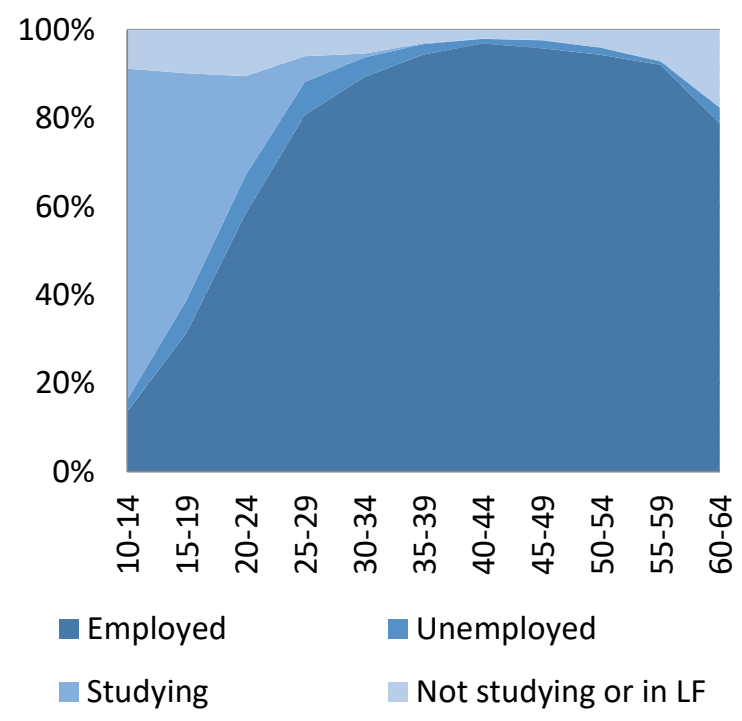

Panel C: Rural Women
Panel B: Urban Men

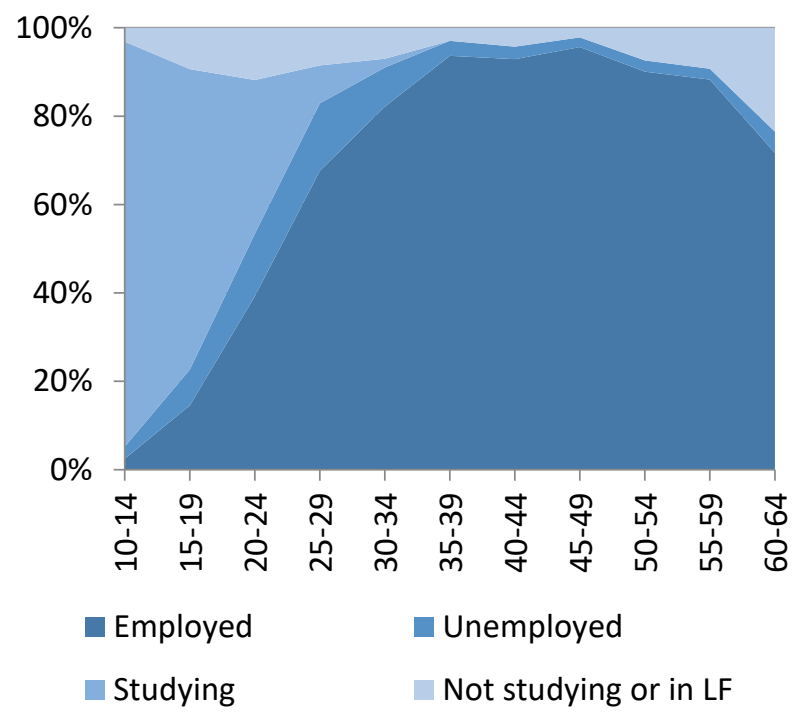

Panel D: Urban Women 

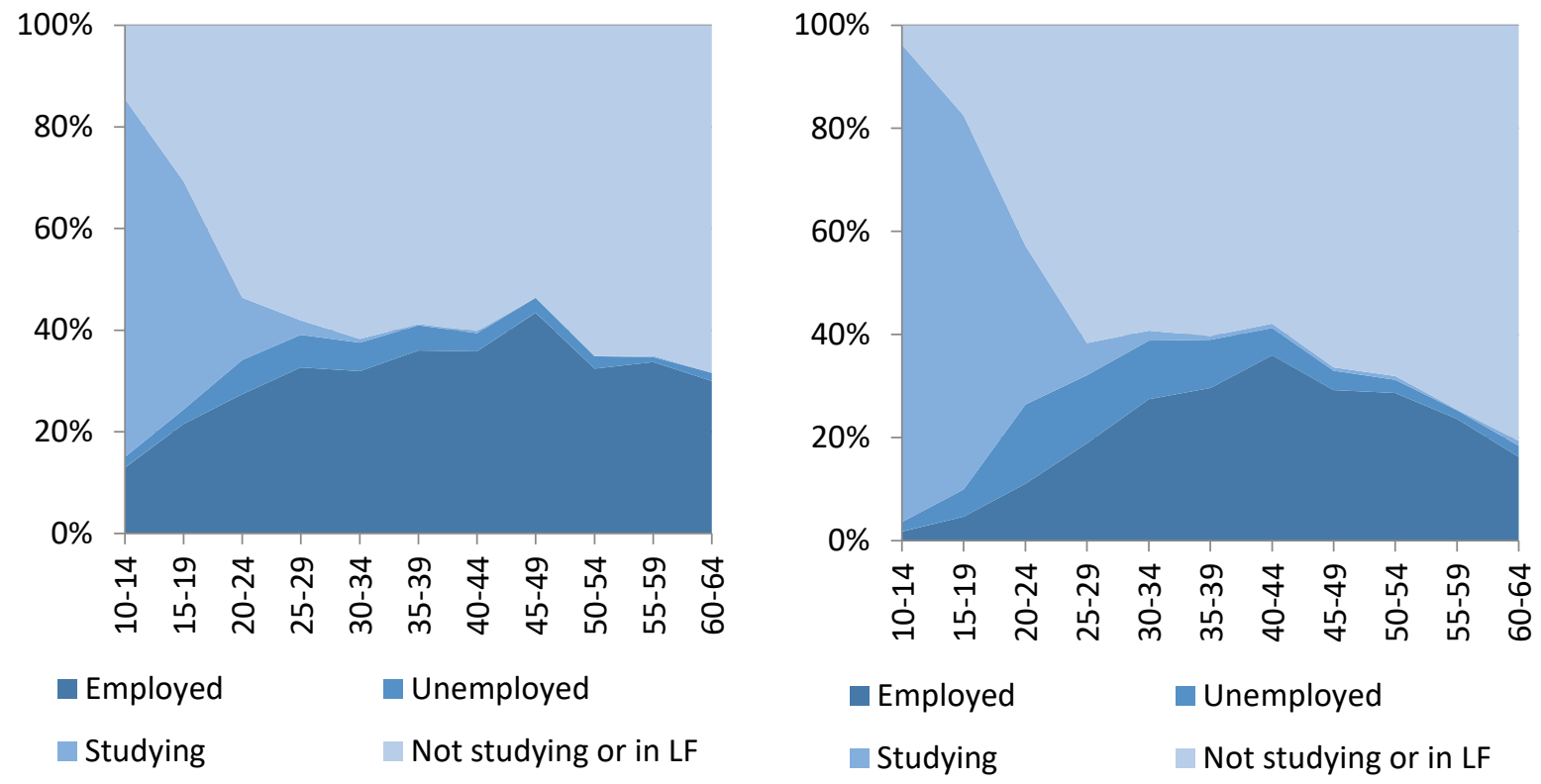

Source: Authors' calculations based on NHBPS 2014/15.

Among those outside of the labor force, women often cite the need to perform household chores while men often cite no hope of finding a job. Figures 9 and 10 show reasons respondents outside of education cited for not participating in Sudan's labor force in 2014. The majority of women who do not participate in the labor market (85 percent) are engaged in household chores. Garlick (2014) argues that this finding reflects a common phenomenon in which formal labor force participation rates substantially understate female economic activity because they do not measure home production. Three in four younger men that do not participate in the labor market do so because they have no hope of finding a job. Older men cite retirement or disabilities as the reason not to participate in the labor market. The number of discouraged young job-seekers is a great concern and in line with a global phenomenon of falling youth labor market participation. This group of unused potential workers represents a challenge as well as an opportunity for Sudan.

Figure 8: Reasons for labor force non-participation by female non-students

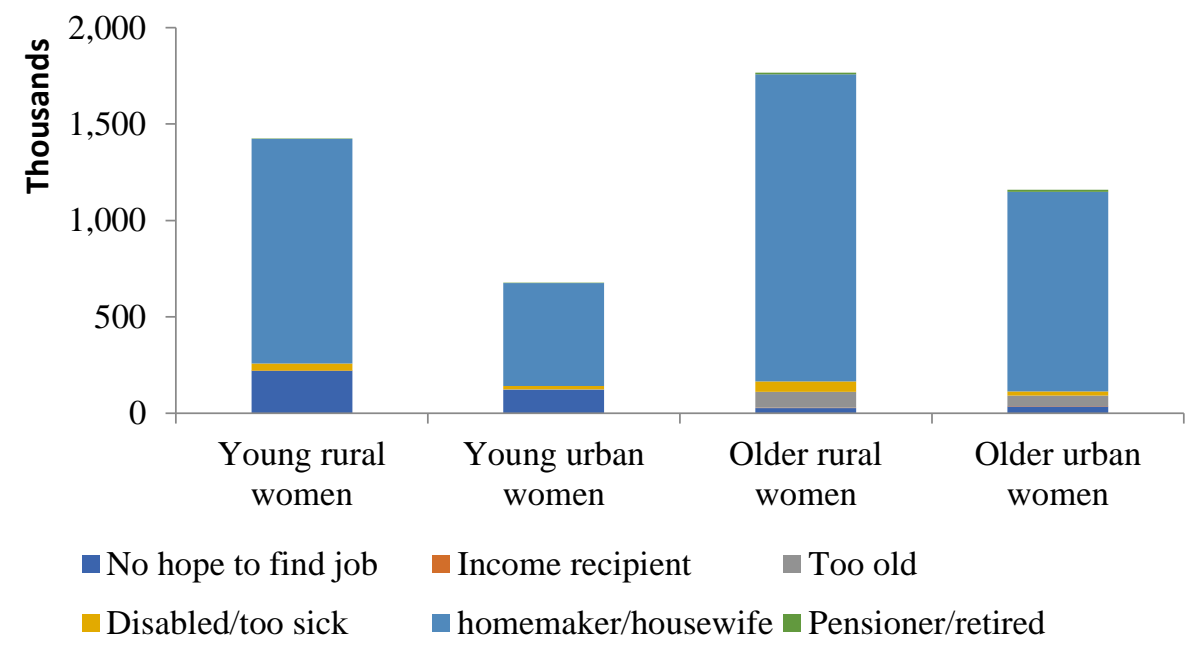


Figure 9: Reasons for labor force non-participation by male non-students

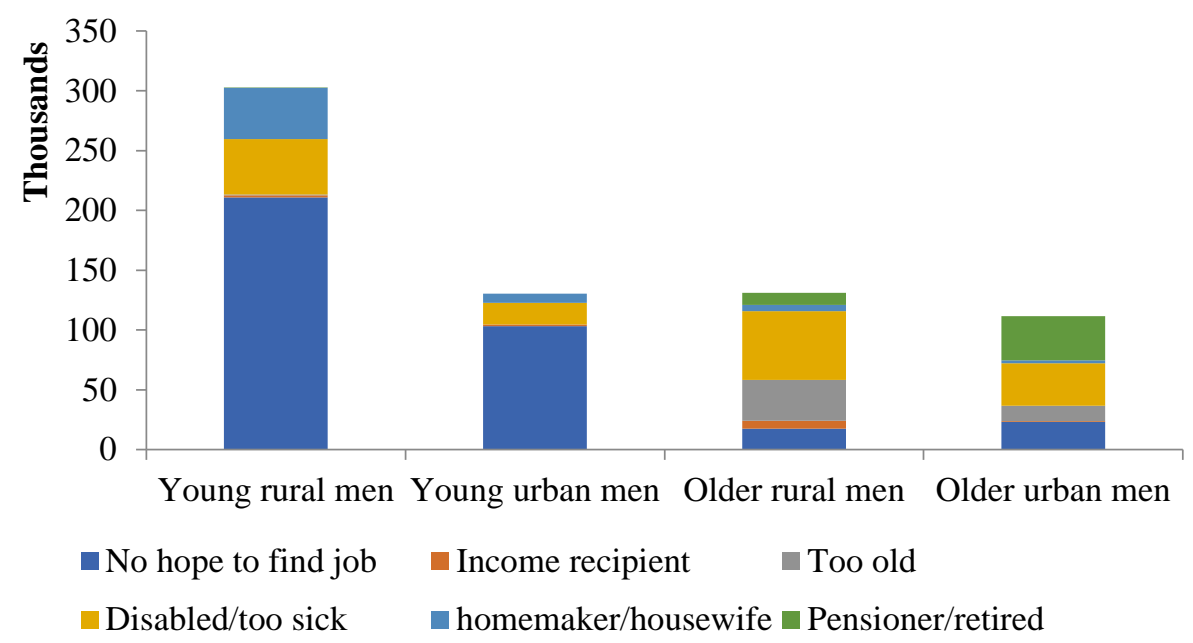

Source: Authors' calculations based on NHBPS 2014/15.

Regression results suggest that the increase in employment between 2009 and 2014 were seasonal rather than structural. While the 2009 survey was conducted in May, the beginning of the lean season, the labor module of the 2014/15 survey was fielded in November of 2014, the main harvest season. As Table 4 shows, the increase in labor force participation over this period does not differ significantly across urban and rural areas. However, it was driven primarily by women entering the labor force. The increase in employment, however, is driven by women in rural areas, with active working-age women in urban areas actually becoming less likely to be in employment. Taken together, this suggests that the observed increase in employment may be driven by a seasonal increase in labor demand seasonal rather than structural (World Bank, 2019).

Table 4: Determinants of labor market participation and employment among working-age adults, 2009-2014 (results from linear probability models)

\begin{tabular}{|c|c|c|c|c|c|c|c|c|}
\hline & (1) & & (2) & & (3) & & (4) & \\
\hline & \multicolumn{4}{|c|}{ Labor force participation } & \multicolumn{4}{|c|}{ Employed } \\
\hline & Estimate & S.E. & Estimate & S.E. & Estimate & S.E. & Estimate & S.E. \\
\hline Age & $0.05 * * *$ & $(0.00)$ & $0.05 * * *$ & $(0.00)$ & $0.02 * * *$ & $(0.00)$ & $0.02 * * *$ & $(0.00)$ \\
\hline Age squared & $-0.00 * * *$ & $(0.00)$ & $-0.00 * * *$ & $(0.00)$ & $-0.00 * * *$ & $(0.00)$ & $-0.00 * * *$ & $(0.00)$ \\
\hline Female & $-0.46 * * *$ & $(0.01)$ & $-0.49 * * *$ & $(0.01)$ & $-0.11 * * *$ & $(0.01)$ & $-0.13 * * *$ & $(0.01)$ \\
\hline Rural & $0.07 * * *$ & $(0.01)$ & $0.08 * * *$ & $(0.01)$ & $0.05 * * *$ & $(0.01)$ & $-0.02 * *$ & $(0.01)$ \\
\hline Year: 2014 & $0.05 * * *$ & $(0.01)$ & $0.02 *$ & $(0.01)$ & $0.02 * *$ & $(0.01)$ & $-0.04 * * *$ & $(0.01)$ \\
\hline Female \& 2014 & & & $0.07 * * *$ & $(0.02)$ & & & $-0.06 * * *$ & $(0.02)$ \\
\hline Rural \& 2014 & & & -0.01 & $(0.02)$ & & & $0.07 * * *$ & $(0.01)$ \\
\hline Rural \& female \& 2014 & & & 0.01 & $(0.02)$ & & & $0.14 * * *$ & $(0.02)$ \\
\hline Constant & $-0.29 * * *$ & $(0.02)$ & $-0.29 * * *$ & $(0.02)$ & $0.51 * * *$ & $(0.03)$ & $0.55 * * *$ & $(0.03)$ \\
\hline$N$ & 62,009 & & 62,009 & & 32,705 & & 32,705 & \\
\hline R-squared & 0.31 & & 0.31 & & 0.06 & & 0.08 & \\
\hline
\end{tabular}

Source: Authors' calculations based on NHBS 2009 and NHBPS 2014/15.

Note: *, **, and *** denote statistical significance at the ten-, five-, and one-percent level. Standard errors clustered at the Primary Sampling Unit (PSU)-level are reported in parentheses.

\section{Characteristics of the Employed}


Structural change?

Agriculture remains the mainstay of a large majority of employed Sudanese, particularly among women, the poor, and in rural areas. The distribution of employment by sectoragriculture, industry, and services - provides information on the state of economic development. The changes in the sectoral distribution of employment over time, particularly structural shifts in employment from agriculture to industry and (in turn) to services - that is, structural transformation - is traditionally seen as the stages of economic development (Lewis 1954; Rostow 1959).

The share of agricultural workers in Sudan increased by 10 percentage points between 2009 and 2014 (Figure 11). This shift was largely at the expense of the services sector and might well reflect differences in the timing of the surveys over the agricultural calendar. A different data source, the World Development Indicators, confirms that the agriculture and services sectors account for the vast majority of employment in Sudan, with manufacturing providing an almost negligible number of jobs (Figure 12). It also shows that the share of agriculture at around one half of the working-age employed has not changed significantly since 2011. Sudan did not follow the same pattern in terms of structural transformation as many of its African counterparts. As discussed in Enache, Ghani, and O'Connell (2016), most African countries have experienced a transition of labor out of agriculture. 
Figure 10: Share of working-age employed by main economic activity (\%)

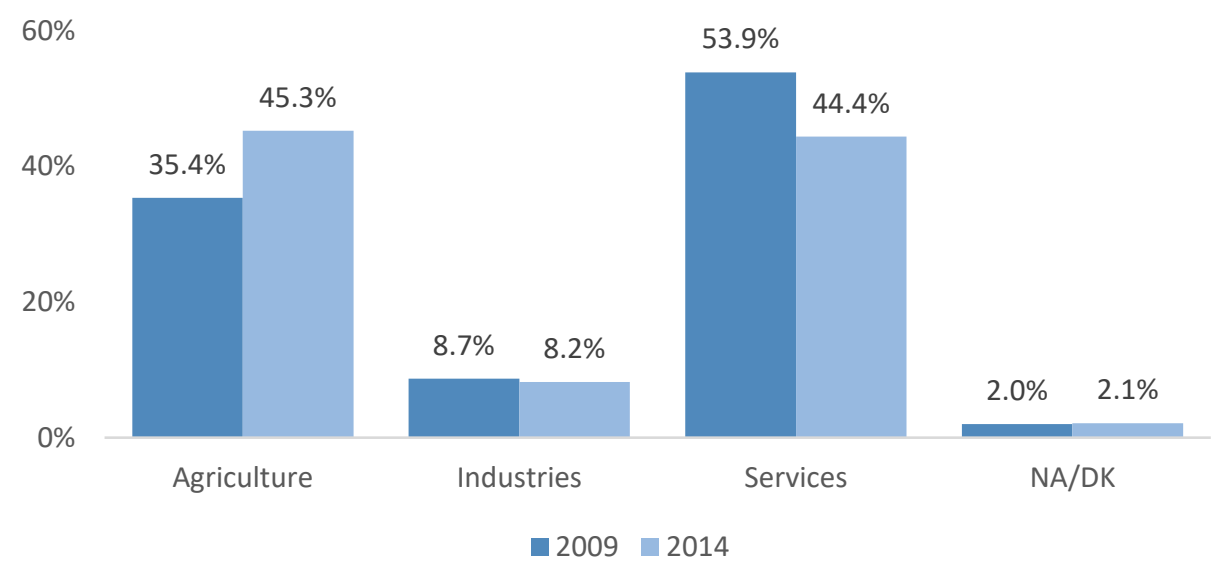

Source: Authors' calculations based on NBHS 2009 and NHBPS 2014/15.

Figure 11: Share of employment by economic sector

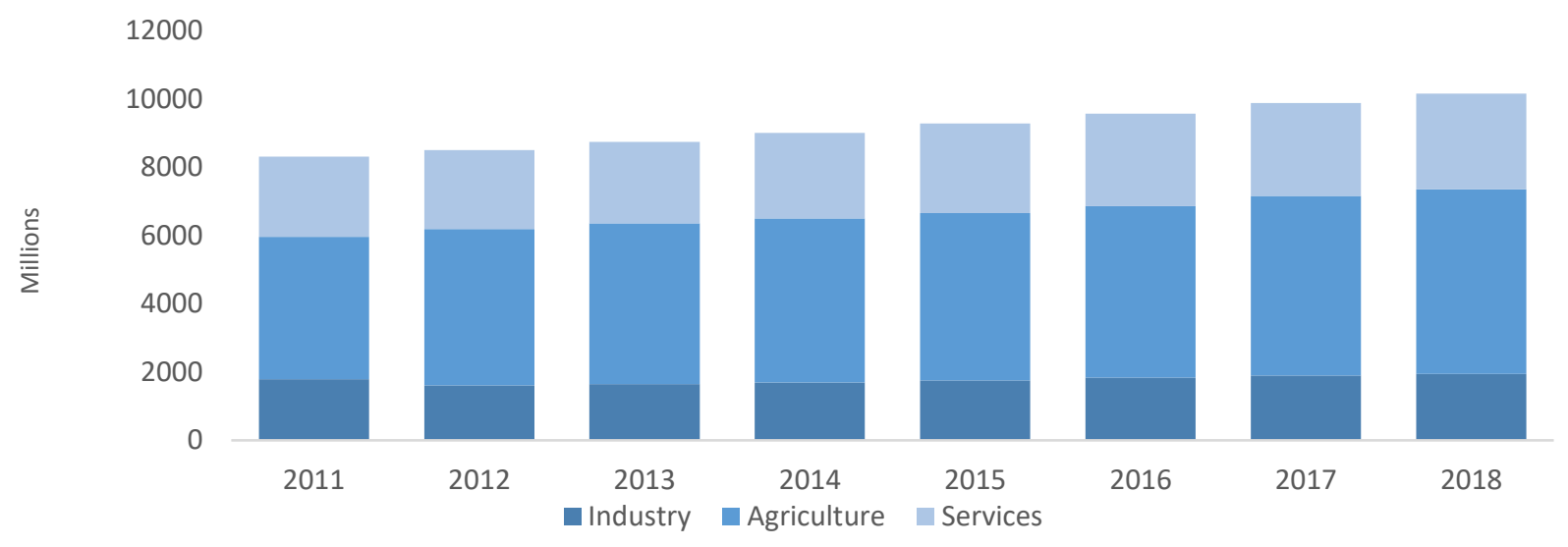

Source: WDI.

Employment in agriculture is more common among women and among the poor. Figure 13 shows that 47 and 44 percent of all employment in Sudan is in agriculture and services, respectively, with only eight percent in industries. In 2014, agriculture accounted for 60 percent of employment among women compared to 39 percent among men. Employment in agriculture is more common among the poor, with a share of 58 percent among the employed bottom 40 percent engaged in agriculture. Non-agricultural jobs are often in services, with industry contributing very little to total employment. Jobs in services and industries are male dominated and more common in urban areas. 
Figure 12: Employment shares by sector, gender, quintile, and locality, 2014

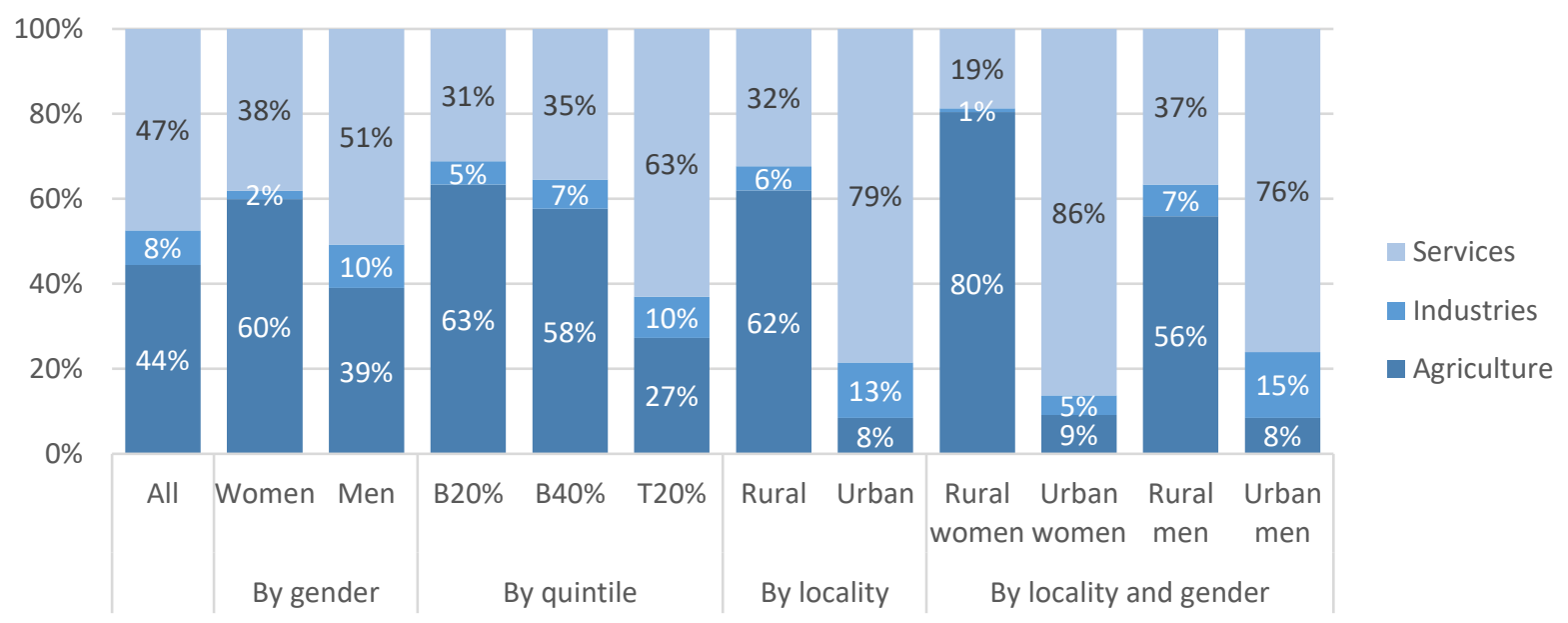

Source: Authors' calculations based on NHBPS 2014/15.

As oil production declined following the secession of South Sudan, artisanal gold mining has become an important economic activity. Non-agriculture job growth was more pronounced in mining and quarrying and in administrative and support service activities. Between 2009 and 2014 job growth in mining and quarrying (which includes oil and gold production) and administrative and support services was more than 160 percent, compared to an increase in the working-age population by around 18 percent (Figure 14). While employment in mining and quarrying increased, daily wages declined. Mining and quarrying jobs shifted from urban areas, particularly Khartoum, to the Northern region and, to a lesser extent, to Kordufan, regions that have known gold extraction sites. Electricity, gas, steam, and air conditioning and the education sector have also expanded their employment share relative to the working-age population. Similarly, the wholesale and retail sectors, transportation, hospitality services, human health, and social work activities have all increased their share of employment over time. The finding that the total number of individuals employed in professional, scientific, and technical activities has declined should be of concern for the country. 
Figure 13: Changes in number of non-agricultural jobs by sector, 2009-2014

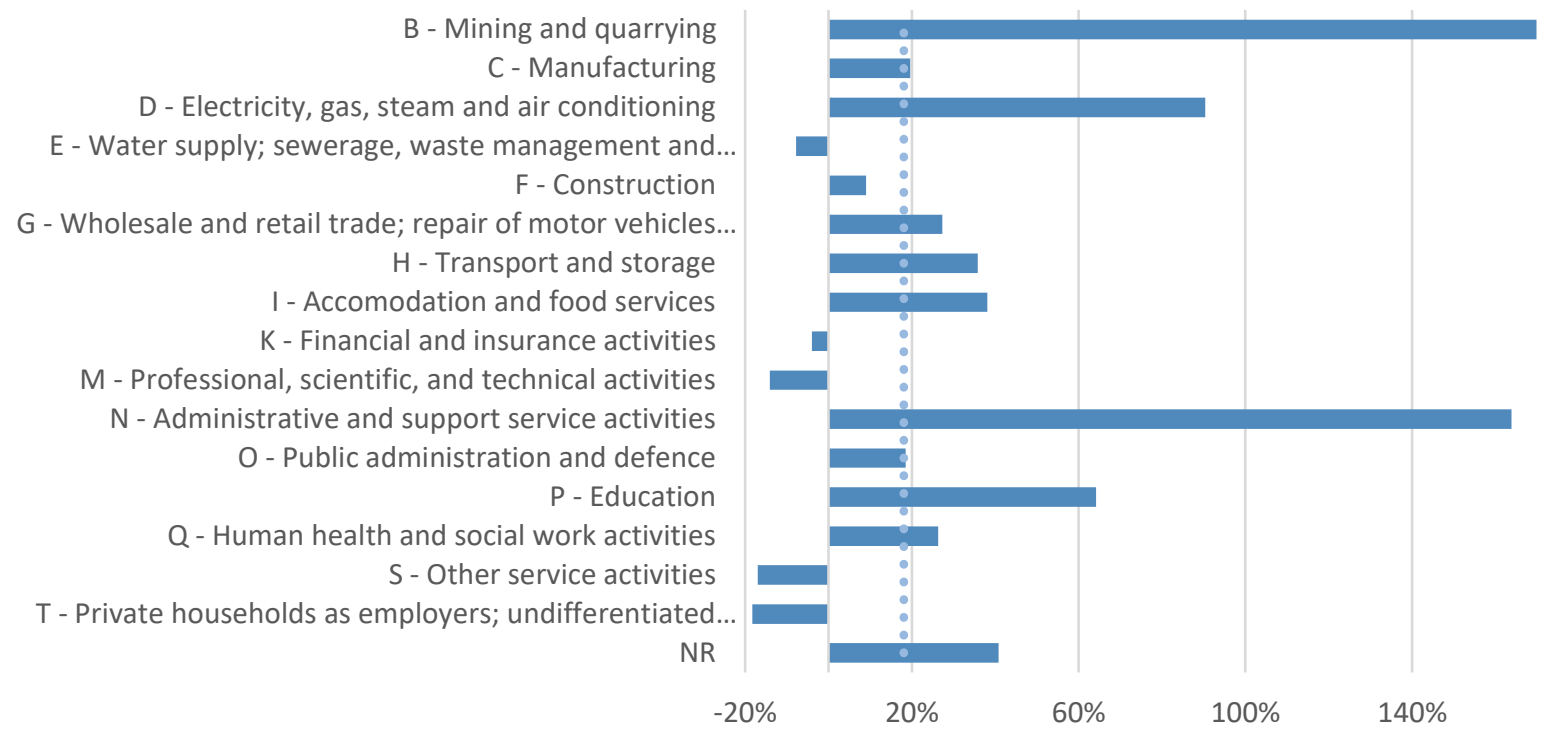

Source: Authors' calculations based on NHBS 2009 and NHBPS 2014/15.

Note: The dotted line indicates growth in the working-age population. Jobs that accounted for fewer than one percent of non-agricultural employment in 2014 are subsumed in the 'Other/NR' category.

\section{Employment type}

Men are more likely to engage in paid employment or own account work. Figures 15 and 16 show the type of employment for different population groups. Most men in both rural and urban areas are paid employees or own account workers. A relatively small fraction of men are employers, and these are mostly drawn from the older cohorts. Unpaid employment within the household is more common in rural areas and concentrated in the agricultural sector.

By contrast, unpaid work within the family is the most common type of employment for women, particularly for younger women in rural areas. Very few women are either employers or own account workers. 
Figure 14: Type of female employment

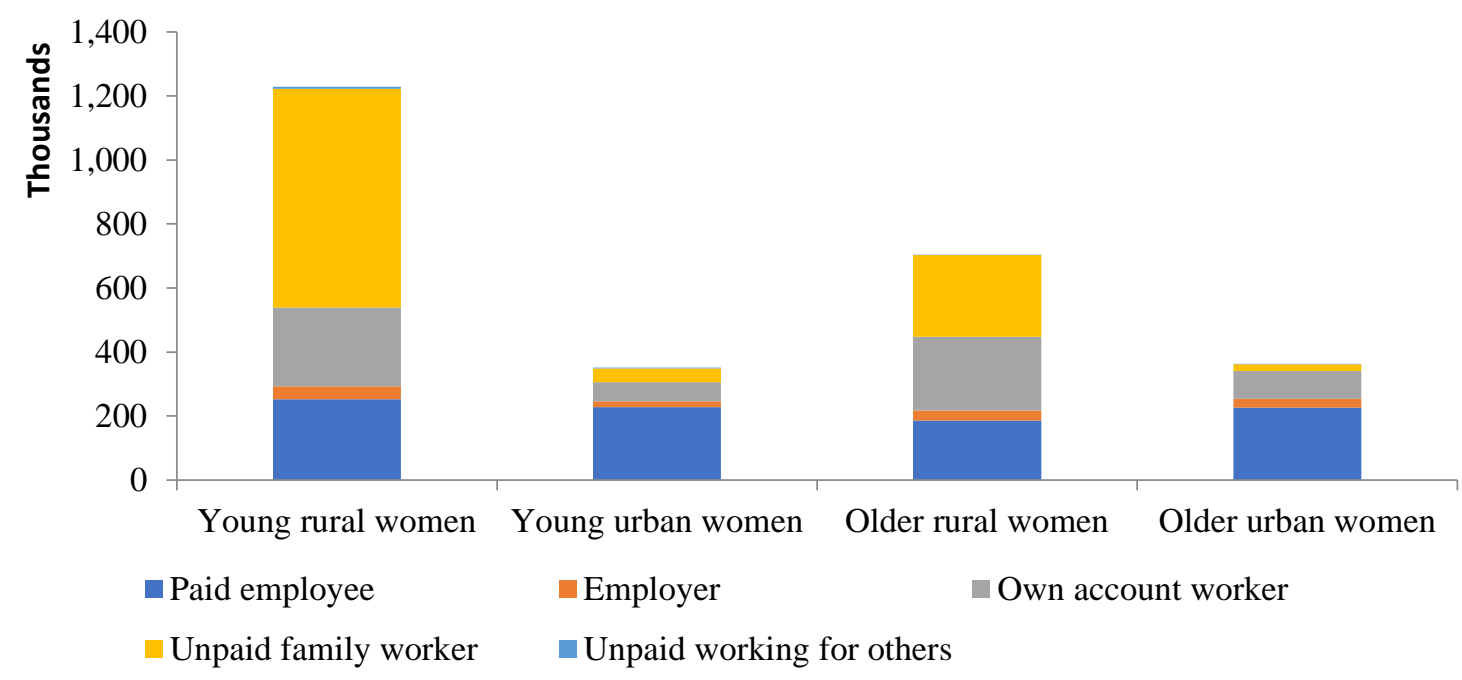

Figure 15: Type of male employment

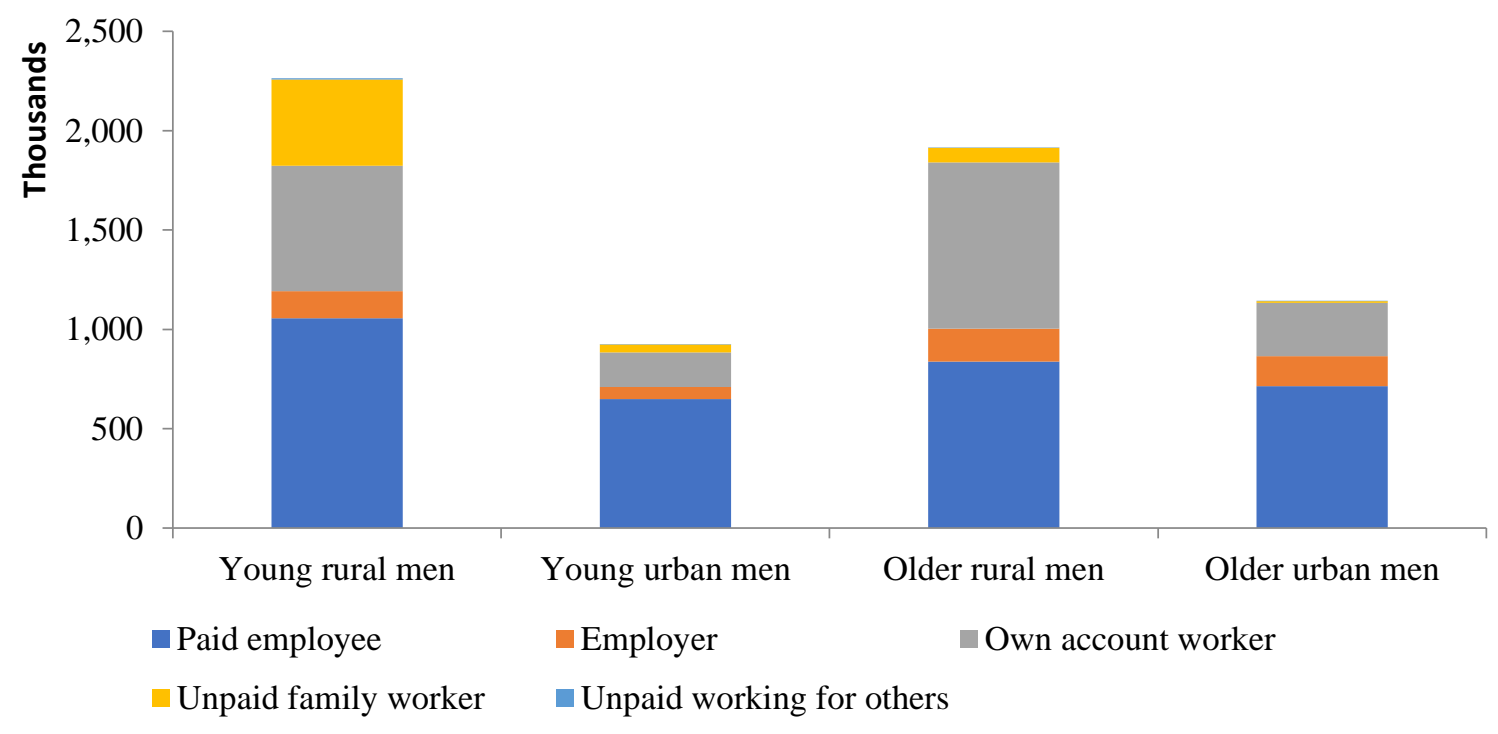

Source: Authors' calculations based on NHBPS 2014/15.

Employment by education level

Returns to secondary and higher education are substantial but declined considerably between 2009 and 2014. Conditional on age and gender, daily wages in 2014 were 12 percent higher for those with secondary education and 34 percent higher for those with post-secondary education when compared with workers with no qualifications (Table 5). Workers with some primary or completed primary surprisingly had lower wages than those without any education. Returns to education in 2009 were considerably higher. For example, workers with post-secondary earned daily wages more than twice as high as those with no qualifications and those with at least some primary still earned 15 percent more. 
More educated Sudanese became less likely to be employed. The 2009 survey does not suggest any significant differences in the probability of being employed between workers with different levels of educational attainment. However, more educated Sudanese were less likely to be employed in 2014. The probability of being employed dropped by 5, 10, and 16 percentage points for those with at least some primary, secondary, and post-secondary education, respectively (Table 5 ). The observed changes in the probability of being employed reflect changes in labor market conditions, with fewer employment opportunities for those with higher educational attainment. Another plausible explanation for this pattern is that given the fall in wages, more educated people may be looking only for better paid (highly skilled) jobs rather than engage in low paid (low skilled) jobs.

Table 5: Educational attainment and labor market outcomes, 2009 and 2014

\begin{tabular}{|l|c|c|c|c|}
\hline & \multicolumn{2}{|c|}{ Employed (LPM) } & \multicolumn{2}{|c|}{ Log daily wage } \\
\hline & $\mathbf{( 1 )}$ & $\mathbf{( 2 )}$ & $\mathbf{( 3 )}$ & $\mathbf{( 4 )}$ \\
\hline & $\mathbf{2 0 0 9}$ & $\mathbf{2 0 1 4}$ & $\mathbf{2 0 0 9}$ & $\mathbf{2 0 1 4}$ \\
\hline Some or completed primary & 0.00 & $-0.05 * * *$ & $0.15^{* * *}$ & $-0.06 *$ \\
\hline & $(0.01)$ & $(0.01)$ & $(0.04)$ & $(0.03)$ \\
\hline Secondary & 0.00 & $-0.10 * * *$ & $0.42^{* * *}$ & $0.12^{* * *}$ \\
\hline & $(0.02)$ & $(0.01)$ & $(0.05)$ & $(0.04)$ \\
\hline Post-secondary and above & -0.03 & $-0.16 * * *$ & $0.77 * * *$ & $0.34 * * *$ \\
\hline & $(0.02)$ & $(0.01)$ & $(0.07)$ & $(0.06)$ \\
\hline Khalwa & 0.01 & 0.00 & -0.07 & $-0.10 *$ \\
\hline & $(0.02)$ & $(0.01)$ & $(0.06)$ & $(0.05)$ \\
\hline DK/NA & -0.01 & $0.02 * *$ & $-0.27 * * *$ & $-0.19 * * *$ \\
\hline & $(0.01)$ & $(0.01)$ & $(0.04)$ & $(0.03)$ \\
\hline Observations & 14,059 & 22,783 & 9,813 & 14,905 \\
\hline R-squared & 0.06 & 0.09 & 0.20 & 0.10 \\
\hline
\end{tabular}

Source: Authors' calculations based on NHBS 2009 and NHBPS 2014/15.

Note: LPM: linear probability model. *,**, and $* * *$ denote statistical significance at the ten-, five-, and one-percent level. Standard errors clustered at the PSU-level are reported in parentheses. The excluded category are individuals with no qualifications. All regressions include age, age squared, and a binary indicator for respondent's gender as controls.

Agriculture is a low-skilled sector as most of those employed in agriculture do not have any formal education. Figure 17 presents employment sector by level of educational attainment. The data show that workers in the agriculture sector are low skilled compared to other sectors. Two in three workers in agriculture have no education and only one in fifty has post-secondary education. The results show that workers in remaining sectors - manufacturing, other industry, and serviceshave relatively similar levels of education. In 2014, the ratio of workers with secondary or postsecondary education to workers with no or primary education was highest in manufacturing (0.99), followed by services (0.94) and industry (0.76), with agriculture scoring far lower (0.14). This skill differential across industrial sectors has clear implications for economic transformation. This implies that rising employment in the manufacturing and mining sectors is likely to require substantial increases in aggregate education levels (Garlick 2014). 
Figure 16: Employment sector by level of educational attainment

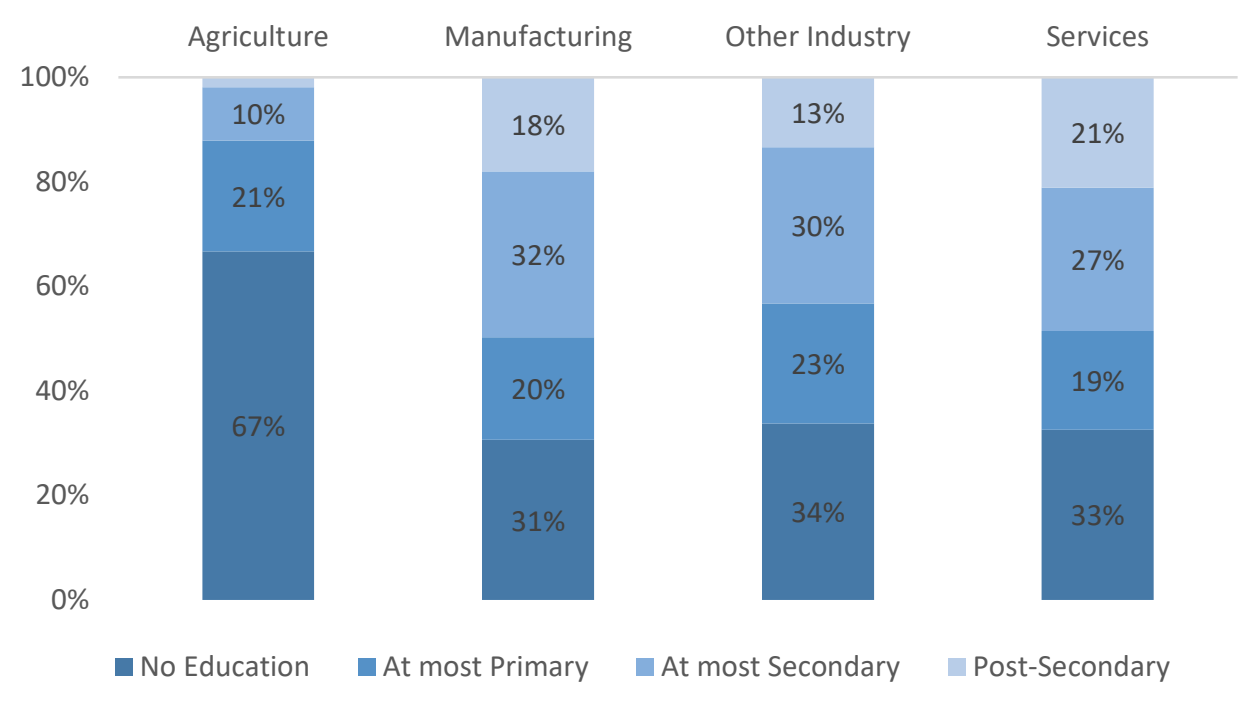

Source: Authors' calculations based on NHBPS 2014/15.

\section{Labor productivity and wages}

Labor productivity

Sudan's real labor productivity decreased considerably during 2009-2014. Average labor productivity, the ratio of real value added to employment, fell in Sudan between 2009 and 2014 at an annual average rate of 4.9 percent. To understand falling labor productivity, the total change was decomposed into its sectoral contributions as well as within sector productivity growth and movements of workers between sectors (Table 6). This shows that falling labor productivity is attributable to declining labor productivity in agriculture and industries, as well as a drop in the share of workers employed in services, which had above-average labor productivity in 2014. 
Table 6: Employment, labor productivity, and decomposition of change in labor productivity by sector, 20092014

\begin{tabular}{|c|c|c|c|c|c|c|c|c|c|}
\hline \multirow[b]{3}{*}{ Year } & \multirow{2}{*}{\multicolumn{2}{|c|}{$\begin{array}{l}\text { Employment } \\
\text { total (millions) }\end{array}$}} & \multicolumn{7}{|c|}{ Labor productivity } \\
\hline & & & \multicolumn{2}{|c|}{$\begin{array}{c}\text { Absolute (SDG, } \\
\text { thousands, } 2009 \\
\text { prices) }\end{array}$} & \multicolumn{2}{|c|}{ Relative to average } & \multicolumn{3}{|c|}{$\begin{array}{l}\text { Decomposition of annual growth rate } \\
\text { in labor productivity }(\%)\end{array}$} \\
\hline & 2009 & 2014 & 2009 & 2014 & 2009 & 2014 & $\begin{array}{l}\text { Within sector } \\
\text { productivity } \\
\text { growth }\end{array}$ & $\begin{array}{l}\text { Structural } \\
\text { change }\end{array}$ & Total \\
\hline Agriculture & 2.7 & 4.6 & 15 & 9 & 0.8 & 0.6 & -2.9 & 1.0 & -1.9 \\
\hline Industries & 0.6 & 0.7 & 56 & 44 & 2.9 & 3.0 & -1.2 & -0.4 & -1.5 \\
\hline Services & 3.8 & 4.1 & 16 & 17 & 0.8 & 1.1 & 0.3 & -1.8 & -1.5 \\
\hline Total & 7.1 & 9.5 & 19 & 15 & 1.0 & 1.0 & -3.8 & -1.2 & -4.9 \\
\hline
\end{tabular}

Source: Authors' calculations based on NHBS 2009, NHBPS 2014/15, and Central Bank of Sudan (2015; 2010).

Note: Calculations based on the decomposition proposed by McMillan and Rodrik (2014).

\section{Wages}

Real wages declined markedly between 2009 and 2014. As Figure 18 shows, between May 2009 and November 2014, mean and median real daily wages declined by about 15 and 22 percent, respectively. However, the median daily wage in 2014 was still around 3.8 times what would be required to be non-poor by the US $\$ 1.90$ poverty line standard. The drop in median real daily wages was driven by urban employees and those at the top end of the welfare distribution(World Bank, 2019).

The decrease in real wages was more pronounced among women, resulting in a widening of the gender wage gap. While men's average wages declined by 10.7 percent, women's wages declined by more than one-third, widening the raw wage gap from 35 percent in 2009 to 40 percent in 2014. These changes may be interpreted in conjunction with increasing labor force participation and employment among women: an increase in the labor supply among women, particularly through greater participation in low-productivity activities such as agriculture, would be expected to result in a decrease in wages. It may also be taken as an indication that women's jobs were more susceptible to adverse economic shocks.

There is no evidence that this wage gap is driven by differences in educational attainment or experience. While women overall tend to have lower educational attainment (see Figure 3), education and age (as a proxy for experience) do not account for the gender wage gap. The reason is that wage-earning women tend to be younger and far more likely to be educated at the postsecondary level or higher than male wage-earners: 25.6 percent of wage-earning women have a post-secondary degree compared to only 10.6 percent of men. It seems that legal and cultural barriers to women's full participation in the labor market. 
Figure 17: Average and median daily wages of employed population (as ratio of the US\$1.90-per person and day poverty line)

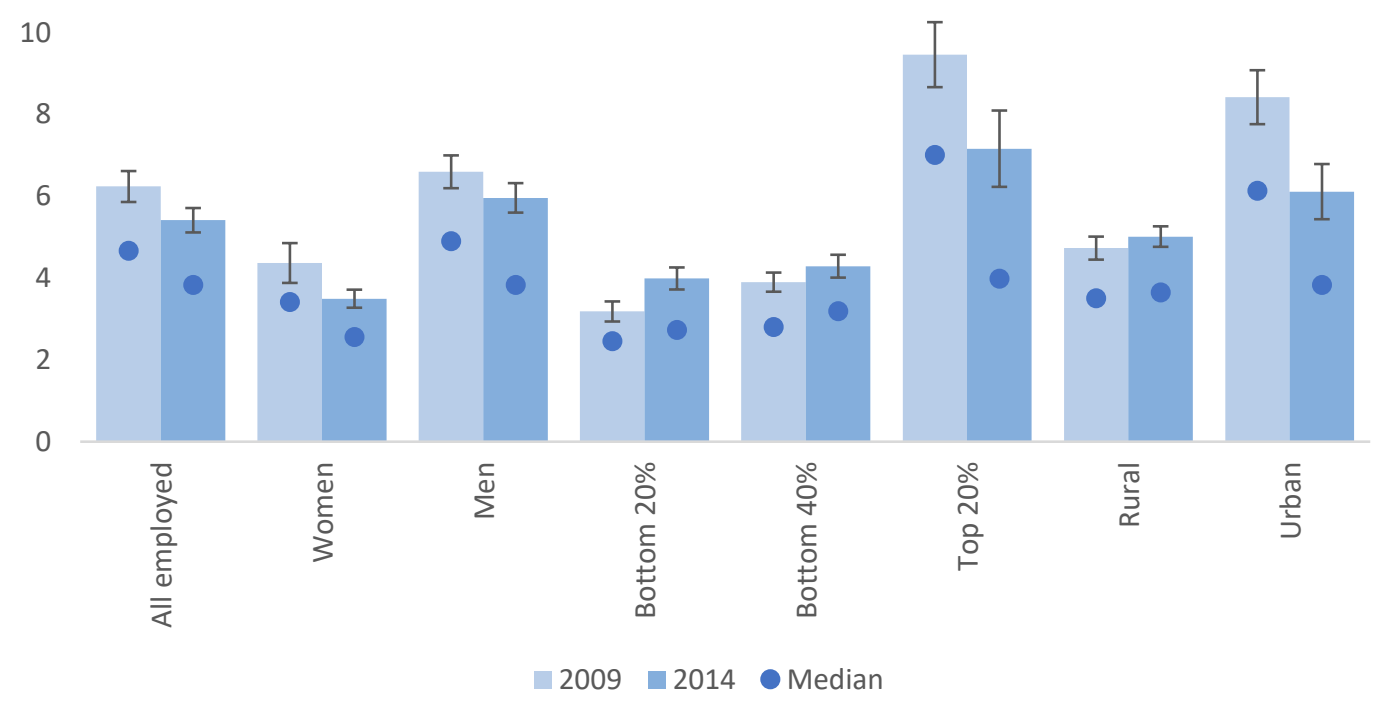

Source: Authors' calculations based on NHBS 2009 and NHBPS 2014/15.

Note: 95 percent confidence intervals indicated.

Wage data used in the construction of the consumer price index (CPI) confirm the decrease in real wages. To construct the CPI series the Central Bureau of Statistics monthly data collection includes an item on weekly wages of domestic servants. The series shows that while nominal wages of domestic servants increased by a factor of about 2.4 , average real wages declined by around 30 percent between January 2010 and November 2014 or 8.7 percent annually (Figure 19).

Figure 18: Nominal weekly salary and real salary of a domestic servant, January 2010 to December 2016

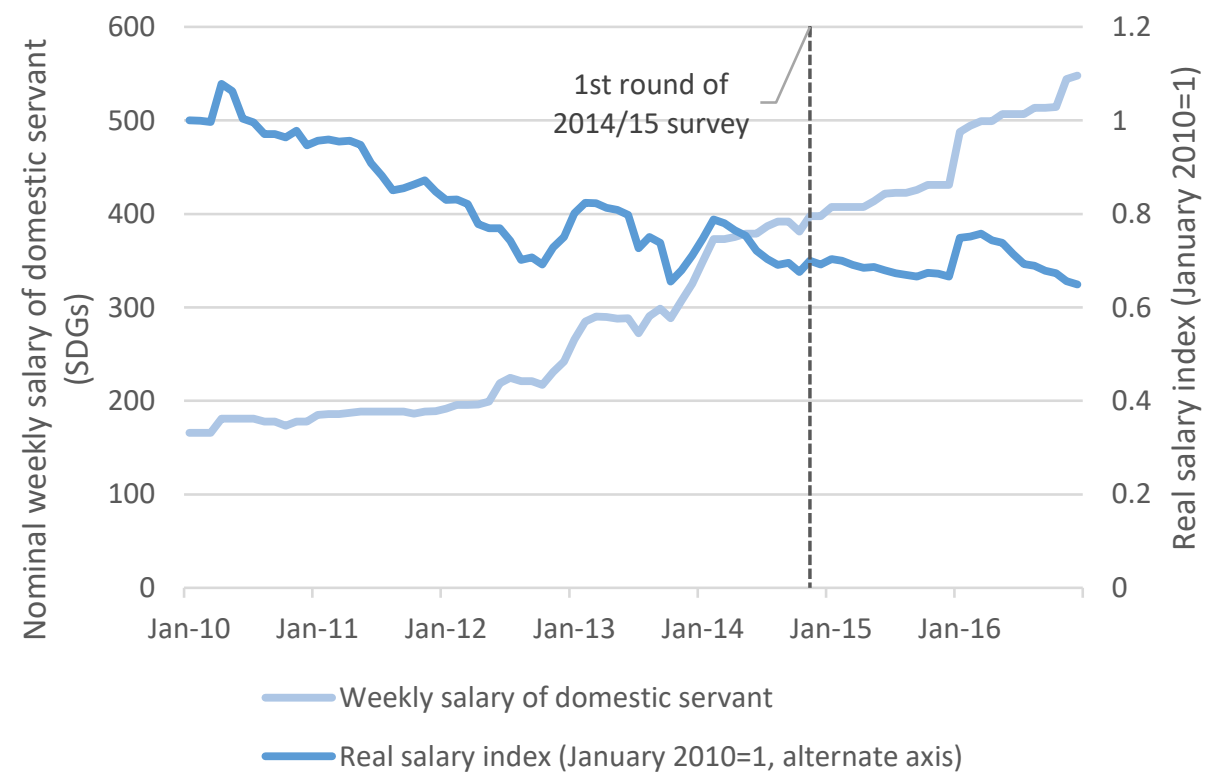

Source: Authors' calculations based on Central Bureau of Statistics CPI data. 
While the survey data suggest an increase in daily wages among crop-farming households, this result likely driven by an increase in seasonal labor demand. Based on the survey data, individuals engaged in crop farming and horticulture experienced an increase in their daily wage by about 4.8 percent per year between May 2009 and November 2014 (Figure 20). Note, however, that this finding is difficult to reconcile with falling labor productivity in agriculture. It seems more likely that it is driven by the difference in timing of field work between the two surveys, i.e. an cyclical increase in demand for agricultural labor during the harvest season.

Figure 19: Annualized change in average real daily wages by sector, May 2009 to November 2014

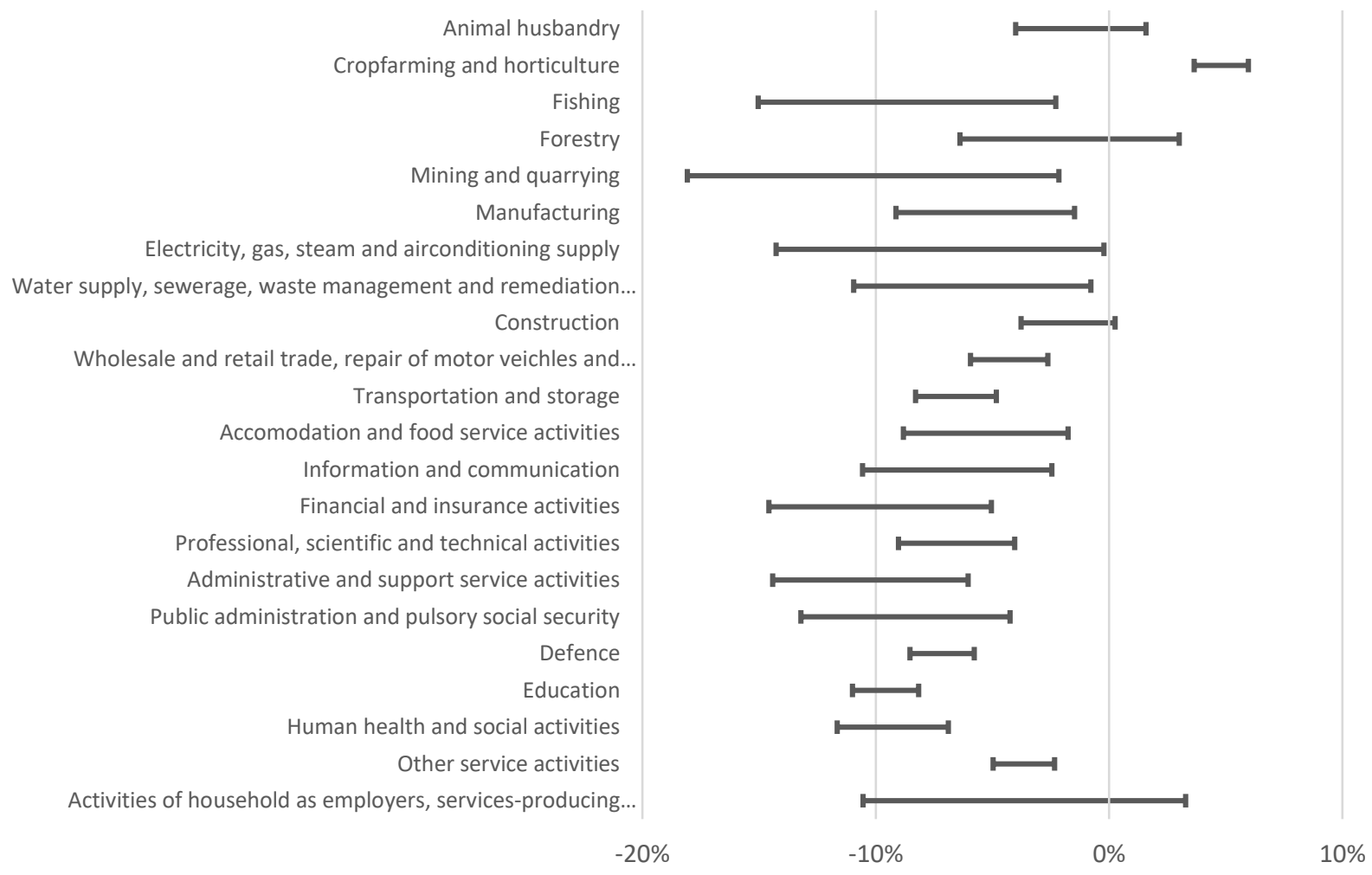

Source: Authors' calculations based on NHBS 2009 and NHBPS 2014/15.

Note: 90 percent confidence intervals indicated.

Real wages declined outside of agriculture, particularly in sectors linked to oil production and those in which the share of civil servants is presumably high. Half of the 10 sectors that saw the largest annual declines are associated with public sector jobs: administrative and support service activities ( -10.2 percent per year), education ( -9.6 percent), human health and social activities $(-9.3$ percent) public administration and social services, and defense $(-7.2$ percent). Other sectors with large wage declines include mining and quarrying $(-10.1$ percent) and transportation and storage ( -6.6 percent), both sectors that are likely to have seen falling labor demand after the end of the oil economy. 


\section{Employment and poverty}

The labor market is the main channel through which economic growth affects poverty. Broad-based, labor-intensive economic growth is the key mechanism by which people are lifted out of poverty. Both the quantity and the quality of employment are crucial for achieving sustainable poverty reduction.

This section examines the role employment plays in poverty reduction. Is having a job a sure way out of poverty in Sudan? How does the incidence of poverty vary by type of employment and sector? To answer these questions, we now look at different indicators of the capacity of jobs to remedy poverty.

More than $90 \%$ of the employed receive wages that suffice to lift them out of extreme poverty. Even though real wages declined between 2009 and 2014 as shown above (Figure 18), only a relatively small fraction of wage recipients received wages below the international poverty line of US\$1.90 per person and day in 2014. Among the poorest quintile in 2014, only 8.9 percent earned below-poverty line wages (Figure 21). Fewer male workers and top 20 percent employees receive wages below the poverty line.

Figure 20: Share of employed earning wages below the US\$1.90 poverty line

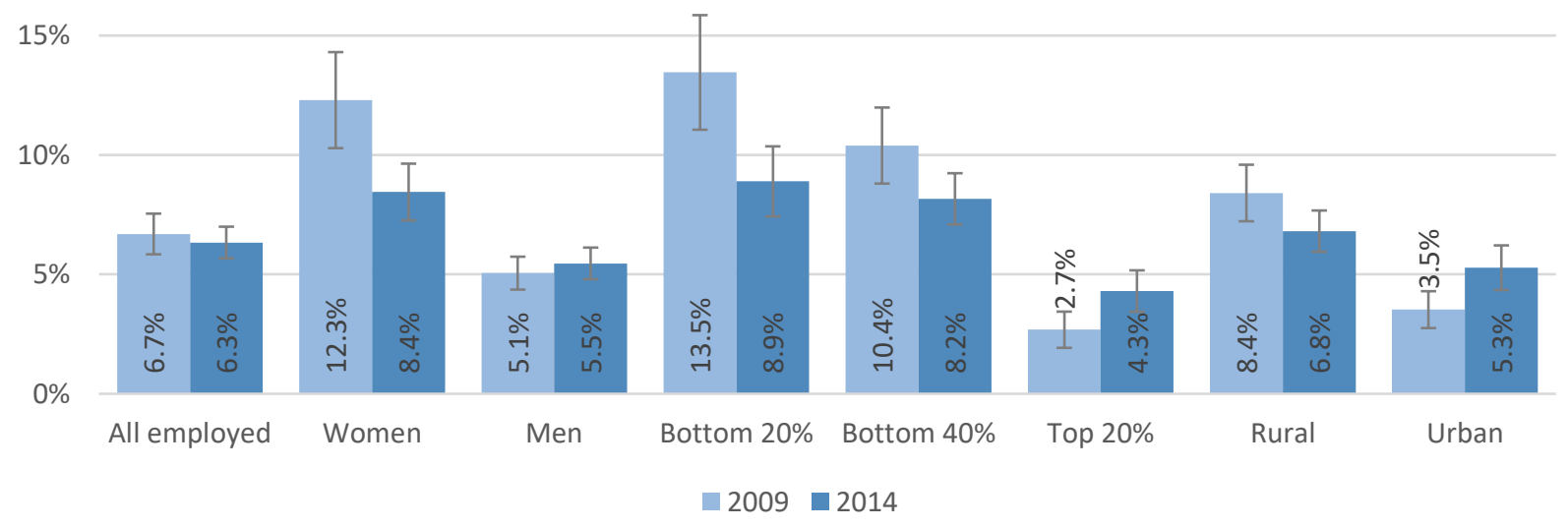

Source: Authors' calculations based on NHBS 2009 and NHBPS 2014/15.

While still high, wage inequality declined by most measures. Visual inspection of the distribution of real wages in 2009 and 2014 (Figure 21) suggests that the lower quintiles held up well while employers from the richest quintile experienced falling real wages. This suggests that wage inequality should have been falling, an interpretation that is also borne out by most measures of inequality: for instance, while daily wages at the 90th percentile in 2009 were 11.4 times higher than at the10th percentile, they were only 7.1 times higher in 2014. The Gini index, on the other hand, indicates an increase in wage inequality from 0.466 to 0.483 (World Bank, 2019).

The unemployed face a higher incidence of poverty than the employed, suggesting that unemployment is a major cause of poverty in Sudan. Individuals living in households with unemployed heads have a one-in-two chance of falling below the poverty line, compared to the 
one-in-three chance of those living with a head who is in employment. The poorest households tend to be those whose head is an unpaid family worker (Figure 22).

Figure 21: Poverty headcount by employment status of household head

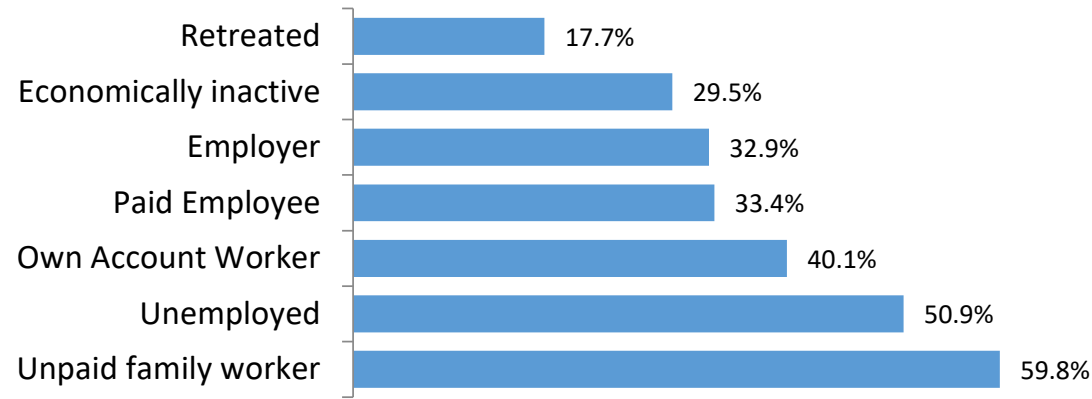

Source: Central Bureau of Statistics, based on NHBPS 2014/15.

Employment in agriculture is associated with a higher likelihood of being poor, but the difference in poverty rates across sectors has declined. The incidence of moderate poverty among Sudanese employed in agriculture was 46.5 percent in 2014, which is much higher than in industries (35.5 percent) and services (34.3 percent) (Figure 23). Moderate poverty remained almost unchanged among agricultural workers but increased in both industries and services.

Figure 22: Poverty incidence (based on US\$3.20 poverty line) by sector of employment

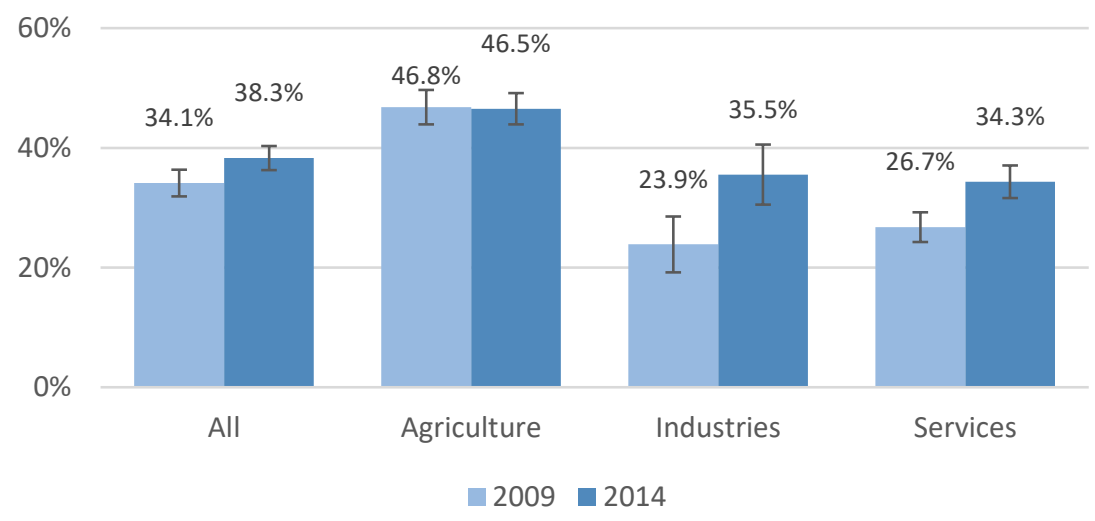

Source: Authors' calculations based on NHBS 2009 and NHBPS 2014/15.

Note: 95 percent confidence intervals indicated.

Households in the bottom 40 percent are more likely to depend on agriculture. In 2014 , the share of households that depend mainly on agriculture was 39 percent for the bottom 40 percent compared to 27 percent for the top 60 percent. The difference is statistically significant at the 5 percent level. It should be noted that households in the bottom 40 percent of the distribution tend to have more members and a larger share of children, exhibit lower levels of education and basic literacy. Bottom 40 percent households are also significantly less likely to use public electricity for lighting, improved sources of drinking water, or improved means of sanitation. Finally, they are more likely to depend primarily on crop farming or animal husbandry (as opposed to wages and salaries, business enterprises, transfers, and so on). 
Unemployment of the household head is associated with higher poverty rates in urban areas. Results presented earlier (Figures 6 and 7) show that the unemployment rate is much higher among the bottom 40 percent of the wealth distribution. Regression results confirm this. Across the population and conditional on household characteristics, unemployment of the household head is associated with a nine-percentage point higher incidence of moderate poverty (Table 7). These effects are more pronounced in urban areas, where unemployment of the household head is associated with a 15-percentage point higher probability of being moderately poor.

Table 7: Relationship between moderate poverty (measured using the US\$3.20 line) and head's employment status, 2014 (linear probability estimates)

\begin{tabular}{|c|c|c|c|c|c|c|}
\hline & (1) & & (2) & & (3) & \\
\hline & Sudan & & Rural & & Urban & \\
\hline Age & $-0.01 * * *$ & $(0.00)$ & -0.00 & $(0.00)$ & $-0.01 * *$ & $(0.00)$ \\
\hline Age squared & $0.00 * *$ & $(0.00)$ & 0.00 & $(0.00)$ & 0.00 & $(0.00)$ \\
\hline Female & $0.07 * * *$ & $(0.02)$ & $0.10 * * *$ & $(0.02)$ & 0.05 & $(0.03)$ \\
\hline Log household size & $0.44 * * *$ & $(0.01)$ & $0.41 * * *$ & $(0.02)$ & $0.49 * * *$ & $(0.02)$ \\
\hline Employer & $-0.07 * * *$ & $(0.02)$ & $-0.09 * * *$ & $(0.03)$ & $-0.05^{*}$ & $(0.03)$ \\
\hline Own-account worker & 0.02 & $(0.02)$ & -0.00 & $(0.02)$ & 0.02 & $(0.03)$ \\
\hline Unemployed & $0.09 * *$ & $(0.04)$ & 0.05 & $(0.05)$ & $0.15 * * *$ & $(0.06)$ \\
\hline Economically inactive & $-0.07 * * *$ & $(0.02)$ & $-0.07 * *$ & $(0.03)$ & -0.05 & $(0.03)$ \\
\hline Other & 0.01 & $(0.05)$ & 0.01 & $(0.05)$ & -0.05 & $(0.07)$ \\
\hline Constant & $-0.15 * *$ & $(0.06)$ & $-0.15 * *$ & $(0.07)$ & $-0.24 * *$ & $(0.11)$ \\
\hline$N$ & 11,953 & & 8,361 & & 3,592 & \\
\hline R-squared & 0.13 & & 0.12 & & 0.16 & \\
\hline
\end{tabular}

Source: Authors' calculations based on NHBPS 2014/15.

Note: $*$, **, and *** denote statistical significance at the ten-, five-, and one-percent level. Standard errors clustered at the PSU-level are reported in parentheses. The excluded type-of-worker category is paid employee.

\section{Conclusion and policy implications}

The rapid rise and subsequent fall of Sudan's oil economy has created significant economic challenges but also some opportunities. Using the most recent household survey data, this paper laid out key features of Sudan's labor market and their relationship to the country's demographic and poverty profile.

Labor market conditions deteriorated after the end of the oil economy. The end of the oil economy and the subsequent macroeconomic instability resulted in sharp decrease in labor demand, resulting in a significant downward-adjustment in wages, especially for women, and increasing unemployment, especially among youth and skilled workers. Differences in the timing of the surveys are likely behind the seemingly positive trend in rural areas with increasing employment and higher wages that still dominate the headline figures.

The analysis also makes it clear that Sudan's labor market is beset with structural challenges that were evident in 2009 as much as in 2014. These include obstacles for women to participate fully in the labor market, resulting in lower participation, higher unemployment rates, and a significant gender wage gap; high youth unemployment; low productivity, especially in agriculture, the mainstay of a large majority of the poor; and low levels of educational attainment, especially among older workers, a significant predictor of employment, wages, and poverty. 
Tackling these structural challenges is key to reaping the benefits of entering the early-dividend stage of the demographic transition.

Based on the findings of this paper, a set of policies to tackle structure challenges would seem to render the labor market more conducive in reducing poverty and boosting shared prosperity in Sudan:

1. Encourage private sector growth. Sudan's labor market challenges are first and foremost supply-side challenges. Expansion of the private sector needs to drive employment and job creation. Yet as of 2020, Sudan ranks $171^{\text {st }}$ out of 190 economies in the World Bank Groups Doing Business ranking (World Bank, 2020). The lack of a vibrant private sector is a key factor contributing to scarcity of jobs in the Sudanese economy. Poor business conditions, such as lack of marketing services and access to credit as well as significant constraints to trading across borders, are deterrents to private sector growth and investment.

2. Overcome gender discrimination in access to basic services and in the labor market. As documents elsewhere by the World Bank, women in Sudan face significant legal constraints in terms of freedom of movement and freedom to pursue different lines of work (World Bank, 2020). The impending PRSP process presents an opportunity to highlight gender equality as a core development objective and as smart economics. A strategy for private sector growth and job creation should have a strong focus on the economic opportunities of women and youth.

3. Invest in agriculture and restore proper incentives. Sudan's agricultural sector, which remains the mainstay of a large portion of Sudan's poor, has long been neglected and remains far below its potential. Ill-advised food price subsidies have long depressed prices and thus incentives for farmers. The PRSP process should explore further how agricultural productivity growth can be restored. Enhancing agriculture's role in poverty reduction requires appropriate incentives for farmers, improved market access, better access to markets and the effective enforcement of property rights.

4. Improve quality of education. A key factor in improving job prospects for Sudanese citizens will be the improvement of access andquality education. 


\section{References}

CBoS. (2010). Annual Report 2010. Khartoum: Central Bank of Sudan.

CBoS. (2015). Annual Report . Khartoum: Central Bank of Sudan.

Christiaensen, L., Demery, L., \& Kuhl, J. (2011). The (Evolving) Role of Agriculture in Poverty Reduction An Empirical Perspective. Journal of Development Economics, 96(2), 239-254.

IMF. (2020). MF Country Report No. 20/7: Sudan Selected Issues. IMF Country Report, International Monetary Fund, Middle East and Central Asia Department, Washington DC. Retrieved from https://www.imf.org/-/media/Files/Publications/CR/2020/English/1SDNEA2020002.ashx

McMillan, M., \& Rodrik, D. (2014). Globalization, Structural Change, and Productivity Growth. World Development, 63, 11-32.

Rodrik, D. (2013). The Past, Present, and Future of Economic Growth. Global Citizen Foundation Working Paper I.

Rodrik, D. (2013). Uncoditional Convergence in Manufacturing. Quarterly Journal of Economics, 128(1), 165-204.

Schwartzstein, P., \& Cecco, L. (2015, December 11). Sudan's Stakes: The 21st-century Gold Rush Where People Work in 19th-Century Conditions. Quartz. Retrieved from https://qz.com/568773/the21st-century-gold-rush-where-people-work-in-19th-century-conditions/

Urdal, H. (2006). A Clas of Generations? Youth Bulges and Political Violence. International Studies Quarterly, 50(3), 607-629.

World Bank. (2015). Africa's Demographic Transition: Dividend or Disaster? Washington, DC: The World Bank Group. doi:10.1596/978-1-4648-0489-2

World Bank. (2015). Sudan: Realizing the Potential for Diversified Development. Washington, DC: The World Bank Group.

World Bank. (2018). Women, Business and the Law 2018. Washington, DC: World Bank Group. Retrieved from

file://C:/Users/WB495217/Downloads/Women,\%20Business\%20and\%20the\%20Law\%202018_ 0.pdf

World Bank. 2019. Poverty and Inequality in Sudan: 2009-2014. Washington, DC: World Bank.

World Bank. (2020). Economy Profile: Sudan. Retrieved from Doing Business: https://www.doingbusiness.org/content/dam/doingBusiness/country/s/sudan/SDN.pdf

World Bank. (2020). Sudan. Retrieved from Women, Business and the Law 2020: https://wbl.worldbank.org/content/dam/documents/wbl/2020/sep/Sudan.pdf 